OECD Environment Working Papers No. 77

\title{
Greening Household Behaviour and Transport
}

\section{Ilka Ehreke,}

Boris Jaeggi,

Kay W. Axhausen 
Organisation de Coopération et de Développement Économiques

Organisation for Economic Co-operation and Development

11-Dec-2014

ENVIRONMENT DIRECTORATE

English - Or. English

\section{ENVIRONMENT WORKING PAPER No. 77 - GREENING HOUSEHOLD BEHAVIOUR AND} TRANSPORT

By Ilka Ehreke, Boris Jaeggi and Kay W. Axhausen (1)

(1) The Institute for Transport Planning and Systems (IVT), Switzerland.

OECD Working Papers should not be reported as representing the official views of the OECD or of its member countries. The opinions expressed and arguments employed are those of the author(s).

Authorised for publication by Simon Upton, Director, Environment Directorate.

JEL Classification: C51, D11, D12, R41, R48.

Keywords: Sustainable transportation, willingness-to-pay, electric vehicles, non-motorized modes, choice model, cycling, walking, environmental attitudes, policy recommendation, household survey.

OECD Environment Working Papers are available at www.oecd.org/env/workingpapers.htm

JT03368450

Complete document available on OLIS in its original format

This document and any map included herein are without prejudice to the status of or sovereignty over any territory, to the delimitation of international frontiers and boundaries and to the name of any territory, city or area. 


\section{OECD ENVIRONMENT WORKING PAPERS}

"OECD Working Papers should not be reported as representing the official views of the OECD or of its member countries. The opinions expressed and arguments employed are those of the author(s).

OECD Working Papers describe preliminary results or research in progress by the author(s) and are published to stimulate discussion on a broad range of issues on which the OECD works.

This series is designed to make available to a wider readership selected studies on environmental issues prepared for use within the OECD. Authorship is usually collective, but principal author(s) are named. The papers are generally available only in their original language -English or French- with a summary in the other language.

Comments on OECD Working Papers are welcomed, and may be sent to:

OECD Environment Directorate, 2, rue André Pascal, 75775 PARIS CEDEX 16, France or by e-mail to env.contact@oecd.org”

OECD Environment Working Papers are published on www.oecd.org/env/workingpapers.htm

This document and any map included herein are without prejudice to the status of or sovereignty over any territory, to the delimitation of international frontiers and boundaries and to the name of any territory, city or area.

The statistical data for Israel are supplied by and under the responsibility of the relevant Israeli authorities. The use of such data by the OECD is without prejudice to the status of the Golan Heights, East Jerusalem and Israeli settlements in the West Bank under the terms of international law.

\section{(C) OECD (2014)}

You can copy, download or print OECD content for your own use, and you can include excerpts from OECD publications, databases and multimedia products in your own documents, presentations, blogs, websites and teaching materials, provided that suitable acknowledgment of OECD as source and copyright owner is given.

All requests for commercial use and translation rights should be submitted to rights@oecd.org 
ENV/WKP(2014)15

\begin{abstract}
This report focuses on personal transport choices. It presents the results of follow-up analysis of the 2011 OECD Survey on Environmental Policy and Individual Behaviour Change (EPIC) survey where econometric techniques are applied. The report complements the overview of the survey data provided in the publication OECD (2014). The objective of the analysis is to understand the determinants of household choices in the following areas: the use of alternative modes of transportation car ownership, willingness-topay for an electric vehicles and the relative importance of environmental factors when buying a car. The results indicate that the choice of non-motorized modes of transportation is strongly correlated with the proximity of the destination and that attitudinal variables play only a minor role. The same is true for the use of public transport. Households that say that they trust information about environmental impact of products, are better educated about impact of private transport and are in favour of government actions to reduce $\mathrm{CO} 2$, tend to have a higher willingness to pay for electric vehicles.
\end{abstract}

JEL Classification: C51, D11, D12, R41, R48.

Keywords: Sustainable transportation, willingness-to-pay, electric vehicles, non-motorized modes, choice model, cycling, walking, environmental attitudes, policy recommendation, household survey. 


\section{RÉSUMÉ}

Ce rapport porte sur le choix du mode de transport personnel. Il présente les résultats de travaux d'analyse qui s'inscrivent dans le prolongement de l'enquête sur la politique de l'environnement et le comportement individuel (EPIC) réalisée par l'OCDE en 2011, et qui ont donné lieu à l'application de techniques économétriques. Ce rapport complète la synthèse des données de l'enquête présentée dans l'ouvrage OCDE (2014). L'analyse vise à cerner les déterminants des choix effectués par les ménages concernant les aspects suivants : utilisation de moyens de déplacement alternatifs, motorisation, consentement à payer pour acquérir un véhicule électrique et importance relative des facteurs environnementaux lors de l'achat d'une voiture. Il en ressort que le recours à des modes de transport non motorisés est étroitement lié à la proximité de la destination et que les variables comportementales ne jouent qu'un rôle mineur. Il en va de même en ce qui concerne l'utilisation des transports publics. On relève généralement un consentement à payer pour acquérir un véhicule électrique supérieur chez les ménages qui déclarent faire confiance aux informations ayant trait à l'impact environnemental des produits, qui sont mieux sensibilisés aux répercussions du transport privé et qui sont favorables aux mesures prises par les pouvoirs publics afin de réduire les émissions de $\mathrm{CO}$.

Classification JEL : C51, D11, D12, R41, R48.

Mots-clés: Transport durable, consentement à payer (CAP), véhicules électriques, modes non motorisés, modèle de choix, vélo, marche, attitudes envers l'environnement, recommandation d'action, enquête ménages. 
TABLE OF CONTENTS

ABSTRACT

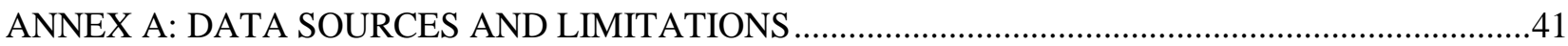

\section{Tables}

Table. 1 Overview of relevant non-motorised mode choice studies .....................................................9

Table 2. Overview of relevant Electric Vehicle (EV) and Hybrid Electric Vehicle (HEV) studies ...........10

Table 3. Variable overview of the binary choice models ........................................................................12

Table 4. Overview of Beta-parameters of binary choice models .............................................................14

Table 5. Overview of mean WTP and socio-economic variables .........................................................24

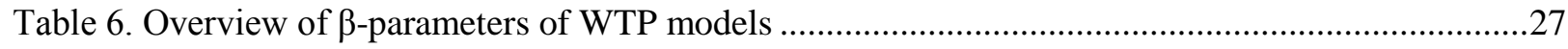

Table 7. Mean importance of car choice attributes, by country …...........................................................

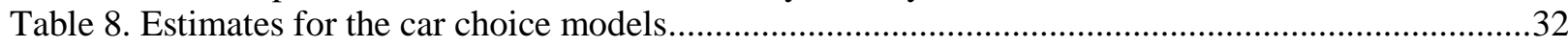

\section{Figures}

Figure 1. Utility impact in model for commuting by foot................................................................15

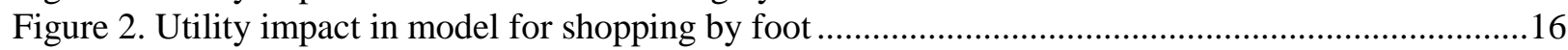

Figure 3. Utility impact in model for commuting by bicycle ..............................................................17

Figure 4. Utility impact in model for shopping by bicycle ...........................................................18

Figure 5. Utility impact in model for commuting by public transport .....................................................19

Figure 6. Utility impact in model for shopping by public transport ........................................................20

Figure 7. Utility impact in car ownership model (part I) …..................................................................21

Figure 8. Utility impact in car ownership model (part II) ......................................................................22

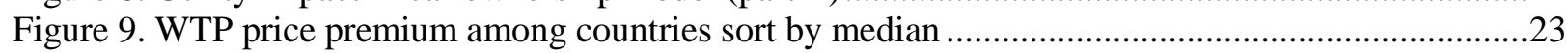

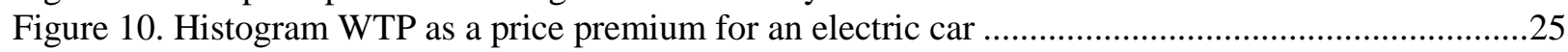

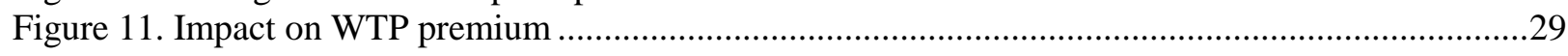

Figure 12. Overview importance of attributes in car choice, all countries .............................................30

Figure 13. Impact on the importance of environmental factors in car choice.........................................33 


\section{INTRODUCTION}

This report focuses on personal transport choices. It presents the results of follow-up analysis of the 2011 OECD Survey on Environmental Policy and Individual Behaviour Change (EPIC) where econometric techniques are applied. The report complements the overview of the survey data provided in OECD (2014).

The models were estimated on the pooled, weighted sample of all countries. In addition, countryspecific models were also estimated. These results will be summarised here, highlighting cases where there are important differences across the findings for different countries.

The report addresses the analysis of policy questions under three headings: choice of alternative modes of transport, the willingness to pay a price premium to purchase an electric car and the importance of environmental impacts relative to other attributes in car choice

\section{Choice of alternative modes of transport}

Decisions about using the alternatives to driving a car - cycling, walking and taking public transport are analysed in this section.

- What are the main factors influencing people's willingness to use alternative transport modes to driving a car?

- How do general attitudes towards the environment affect the decision to cycle, walk, or take public transport?

- What are the characteristics of those individuals who are reluctant to use these alternative modes?

- Which characteristics of public transport encourage households most to use it instead of driving? How do these characteristics vary across the countries surveyed?

- How is household car ownership and car use influenced by the availability of public transport options?

\section{The willingness to pay a higher price for an electric car}

In this section we examine respondents' willingness-to-pay (WTP) more for an electric vehicle than for a conventional car. Key questions underlying the analysis are:

- How much more are households willing to pay for an electric car? How does it vary across countries surveyed?

- What are the characteristics of those individuals who are most reluctant to pay a higher price for the purchase of an electric car?

- Does willingness-to-pay vary significantly across household groups? Does WTP vary with attitudinal characteristics? Does WTP vary with political context? 
When buying a new car, diverse factors influence travellers' choices. Each traveller values these factors differently. This section analyses the importance of environmental factors relative to other attributes in car choice. The key questions are:

- What is the importance of environmental impacts for those who do not own a car?

- What are the most important characteristics of the vehicle when choosing a car? How do preferences vary across countries?

- How do general attitudes towards the environment affect the importance of different factors in car choice?

- How do preferences in car attributes vary across household types?

- How does political context affect preferences in car attributes? 


\section{LITERATURE OVERVIEW}

Most of the existing literature on transportation mode choice focuses on commuters' choices between driving a car and taking public transport. Since 1977, a multitude of studies have analysed the influence of travel time, travel cost, reliability, etc. of the two modes. These studies are not part of this literature review, because Value of Travel Time Savings (VTTS) is already a well-known and integrated concept, and the OECD 2011 survey did not gather data for such an analysis. Also not included herein is a review of literature on car ownership, car use and public transport use, as these topics are very well covered in OECD (2014). This section focuses on studies of non-motorised mode choices and Willingness-to-Pay (WTP) for Electric Vehicles (EV) and other alternative fuel vehicles.

\section{$1 \quad$ Non-motorised transport modes}

Studies of households' (or commuters') choice of non-motorised modes such as walking or cycling follow a different approach than studies on motorised modes. A choice between motorised and nonmotorised modes cannot be reduced to travel time and cost. The choice of a non-motorised mode often takes into account destination choice; therefore a broader, more integrative approach is needed. Most studies compare different regions, cities or neighbourhoods and look for correlations between population density, land use and transportation infrastructure on the one hand and mode shares of walking and cycling on the other. Some studies also include socio-economic variables. The results are fairly consistent: walking and cycling are more frequent in areas with high workplace and residential density or a stronger land use mix (destinations with shorter trips can be chosen) and in areas with more favourable walking and cycling infrastructure. Long distances negatively influence non-motorised mode choices. The most important socio-economic variable is income, but the results are ambiguous. When income is so low that it inhibits car ownership, walking is often chosen out of necessity. On the other hand, the study by Parkin et al. (2008) shows that economic deprivation has a negative effect on cycling. Table 1 gives an overview of the relevant studies. 
Table 1. Overview of relevant non-motorised mode choice studies

\begin{tabular}{|c|c|c|c|c|c|c|}
\hline & $\begin{array}{c}\text { High population } \\
\text { density } \\
\text { accessibility }\end{array}$ & $\begin{array}{c}\text { Favourable* } \\
\text { infra-structure }\end{array}$ & $\begin{array}{l}\text { High land } \\
\text { use mix }\end{array}$ & Gender & $\begin{array}{c}\text { Low income, } \\
\text { no car } \\
\text { ownership }\end{array}$ & $\begin{array}{c}\text { Long trip } \\
\text { distance/ travel } \\
\text { time }\end{array}$ \\
\hline $\begin{array}{l}\text { Pinjari and } \\
\text { Bhat (2007) }\end{array}$ & $\begin{array}{l}\text { + Walking / } \\
\text { Cycling }\end{array}$ & $\begin{array}{l}+ \text { Walking / } \\
\text { Cycling }\end{array}$ & $\begin{array}{c}\text { + Public } \\
\text { transport } \\
\text { usage }\end{array}$ & & $\begin{array}{l}\text { + walking / } \\
\text { cycling }\end{array}$ & \\
\hline $\begin{array}{l}\text { Frank and } \\
\text { Pivo (1994) }\end{array}$ & $\begin{array}{c}\text { + Walking/ } \\
\text { Transit } \\
\text { Thresholds at } 13 \\
\text { persons/acre } \\
\text { origin and } 125 \\
\text { workplaces/acre } \\
\text { destination }\end{array}$ & & $\begin{array}{c}\text { + Transit } \\
\text { usage }\end{array}$ & & & \\
\hline $\begin{array}{l}\text { Frank et al. } \\
\qquad(2008)\end{array}$ & $\begin{array}{c}\text { + Transit / } \\
\text { Walking / Cycling }\end{array}$ & & $\begin{array}{l}\text { + Public } \\
\text { transport / } \\
\text { Walking/ } \\
\text { Cycling }\end{array}$ & $\begin{array}{c}\text { Male + } \\
\text { Walking/ } \\
\text { Cycling, } \\
\text { Female + } \\
\text { Transit }\end{array}$ & & \\
\hline $\begin{array}{l}\text { Saelens et al. } \\
\qquad(2003)\end{array}$ & $\begin{array}{c}\text { + Walking / } \\
\text { Cycling }\end{array}$ & $\begin{array}{l}\text { + Walking / } \\
\text { Cycling }\end{array}$ & $\begin{array}{c}\text { + Transit / } \\
\text { Walking / } \\
\text { cycling }\end{array}$ & & & $\begin{array}{l}\text { - Walking / } \\
\text { Cycling }\end{array}$ \\
\hline $\begin{array}{l}\text { Hess et al } \\
\text { (1999) }\end{array}$ & & + Walking & & & + Walking & \\
\hline $\begin{array}{l}\text { Cevero and } \\
\text { Kockelman } \\
(1997)\end{array}$ & $\begin{array}{c}\text { + Walking / } \\
\text { Cycling } \\
\text { - Car ownership } \\
\text { and usage }\end{array}$ & $\begin{array}{c}\text { + Walking / } \\
\text { Cycling / transit }\end{array}$ & $\begin{array}{c}\text { + Walking / } \\
\text { Cycling / } \\
\text { transit }\end{array}$ & & + Walking & $\begin{array}{l}\text { - Walking / } \\
\text { Cycling }\end{array}$ \\
\hline $\begin{array}{l}\text { Parkin et al. } \\
(2008)^{\star}\end{array}$ & & + Cycling & & & - Cycling & - Cycling \\
\hline
\end{tabular}

* Parkin et. al. (2008) offers great details on infrastructures favourable to cycling use such as off road cycle paths or low motorized traffic flows. Other research shows high intersection density and low block length as favourable to nonmotorized modes.

\section{Willingness-to-pay (WTP) for alternative fuel vehicles}

Research on car choice or fleet choice has focused either on car ownership (the number of vehicles per household) or car type. In recent years, interest in low emission vehicles such as Hybrid Electric Vehicles (HEV) and Electric Vehicles (EV) on the part of researchers, car manufacturers and politicians has increased. However, the data needed to conduct studies on the choice of alternative fuel vehicles are scarce. Moreover, market penetration is still low meaning that estimates of determinant factors are likely to be unreliable. Besides, market conditions are rapidly changing and infrastructure often does not exist yet. Assessing the WTP for electric vehicles is of great interest to both car manufacturers and politicians, but results can be very uncertain: the consumer is generally not familiar with the product for which he is supposed to state his WTP, nor has he any experience in using it. Furthermore, the final product (EV) is 
not yet developed and great uncertainties exist, particularly in the area of battery cost/lifespan and range. Therefore, WTP estimates are often influenced by a social desirability bias or a consumer's expectations for the future (due to recent media coverage, for example) and must be interpreted with caution. This also explains the wide range of WTP figures found in the literature ranging from USD minus 2,000 to plus 10,000 . Table 2 gives an overview of the relevant studies.

Table 2. Overview of relevant Electric Vehicle (EV) and Hybrid Electric Vehicle (HEV) studies

\begin{tabular}{|c|c|c|}
\hline & WTP for EV or HEV or attributes & $\begin{array}{l}\text { Socioeconomic Influence on EV, HEV or } \\
\text { low emission cars or attributes }\end{array}$ \\
\hline Achtnicht (2012) & $\begin{array}{l}\text { High negative constant indicates no } \\
\text { positive WTP for EV }\end{array}$ & $\begin{array}{l}\text { Higher WTP for low emission cars for } \\
\text { younger persons, women and highly } \\
\text { educated. Between } 12 € / g \text { CO2 for older } \\
\text { men with small budget and low education to } \\
127 € / g \text { CO2 for younger women with high } \\
\text { education and budget. }\end{array}$ \\
\hline \multirow[t]{6}{*}{ Hidrue et al. (2010) } & $\begin{array}{l}\text { WTP dependent on EV configuration. Median from }-2.000 \\
\text { USD (low range and long charging time) to } 9.600 \text { USD (high } \\
\text { range short charging time) }\end{array}$ & \multirow{6}{*}{$\begin{array}{l}\text { High orientation towards EV: Young people } \\
\text { expecting rising gas prices, environmentally } \\
\text { friendly, early adopter, male, likes small } \\
\text { cars. }\end{array}$} \\
\hline & WTP dependent on orientation: & \\
\hline & $\begin{array}{l}\text { EV oriented: } 2.300, \text { GV oriented }-22.000 \text {, average }-7.000 \\
\text { USD }\end{array}$ & \\
\hline & $\begin{array}{l}\text { WTP for range } 300 \text { miles: } 7.600 \text { to } 17.800 \text { USD ( } \$ 35 \text { to } \$ 75 \\
\text { for one mile of added driving range) }\end{array}$ & \\
\hline & $\begin{array}{l}\text { WTP for charging time: } 1.000 \text { ( } 5 \text { hours) to } 11.100 \text { USD (10 } \\
\text { min.) }\end{array}$ & \\
\hline & $\begin{array}{l}\text { WTP for lower emissions: } 1.600 \text { ( } 50 \% \text { lower) to } 5.100 \text { USD } \\
\text { (95\% lower) }\end{array}$ & \\
\hline $\begin{array}{l}\text { Ewing and Sarigöllü } \\
(2000)\end{array}$ & $\begin{array}{l}\text { Strong preference towards low emission and EV if capability } \\
\text { of EVs is same as conventional vehicles }\end{array}$ & \\
\hline \multirow[t]{2}{*}{$\begin{array}{l}\text { Potoglou and } \\
\text { Kanaroglou (2007) }\end{array}$} & $\begin{array}{l}\text { WTP for low }(10 \%) \text { emission vehicle range from } 2.000 \text { to } \\
4.800 \text { CAN\$. }\end{array}$ & $\begin{array}{l}\text { Important attributes are fuel efficiency, fuel } \\
\text { availability and low emissions. }\end{array}$ \\
\hline & $\begin{array}{l}\text { WTP for saving } 1.000 \text { CAN\$ in fuel costs range from } 2.200 \text { to } \\
5.300 \text { CAN } \$ \text {. }\end{array}$ & \\
\hline Axsen et al. (2003) & $\begin{array}{l}\text { WTPs for HEV from } 2.000 \text { to } 3.500 \text { USD (SP Data) and } \\
\text { average of }-12.000 \text { USD (RP Data) }\end{array}$ & \\
\hline Erdem et al. (2010) & WTP for HEV in average 560 USD (Turkey) & \\
\hline $\begin{array}{l}\text { Ong and Hasselhoff } \\
(2005)\end{array}$ & WTP for HEV $10 \%$ of purchase price. & \\
\hline \multirow[t]{2}{*}{ Dagsvik et al (2002) } & $\begin{array}{l}\text { WTP for EV (all attributes equal) } 250 \text { (men } 50+\text { ) to } 8.400 \text { USD } \\
\text { (women 30-49) }\end{array}$ & \\
\hline & $\begin{array}{l}\text { WTP for HEV (all attributes equal) } 3.500 \text { (men 18-29) to } 9.900 \\
\text { USD (women 30-49) (Norway) }\end{array}$ & \\
\hline
\end{tabular}




\section{CHOICE OF ALTERNATIVE MODES}

In this section, results are presented from the analysis of households' choice of transport modes other than car use. In the given datasets, households stated which mode they use for commuting and shopping, but they did not choose their preferred mode among a given choice set for the same trip. Therefore, we only have information on the chosen alternative, not on those modes not chosen. The model form for this kind of information is a Binary Logit model that identifies the variables influencing a household's choice for a particular mode. Three different modes - walking, cycling, and public transport - are analysed, each for the purposes of commuting and shopping. In addition to these six models, a binary car ownership model was estimated to identify a household's reasons for owning (or not owning) a car.

In all seven models, focus was placed on attitudinal variables to test the hypothesis that households with a more environmentally friendly attitude use alternative modes more often. The various indexes given in the dataset were tested and showed a statistically significant impact. However, this impact varies widely and is relatively small. The models were developed and estimated using the pooled dataset. Table 4 shows the estimated coefficients in summary form for all seven models.

In the following sections, each model is discussed in detail and relevant differences between countries are mentioned. Table 3 shows the variables of the binary choice models. 
Table 3. Variable overview of the binary choice models

\begin{tabular}{|c|c|c|c|c|c|c|}
\hline Variable & Category & Min & Max & Mean & Count & Freq. \\
\hline \multicolumn{7}{|l|}{ Travel Time } \\
\hline Commuting time & & 0 & 88.6 & 12.03 & & \\
\hline TT savings by car & & -30 & 30 & 4.73 & & \\
\hline Minutes to public transport & & 2.3 & 43.9 & 7.56 & & \\
\hline \multicolumn{7}{|l|}{ Socio-economic } \\
\hline Income & & 0 & 159160 & 32490 & & \\
\hline Income Perception & & 1 & 7 & 4.42 & & \\
\hline Age & & 18 & 69 & 41 & & \\
\hline Education & & 0 & 8 & 3.36 & & \\
\hline HH Size & & 1 & 6 & 3 & & \\
\hline \multicolumn{7}{|l|}{ Indices } \\
\hline Environmental index 1 & & 0 & 10 & 7.82 & & \\
\hline Environmental index 2 & & -2 & 2 & 0.53 & & \\
\hline Policy index & & 0 & 10 & 6.95 & & \\
\hline Local environment index & & -2 & 1.8 & -0.16 & & \\
\hline \multirow[t]{2}{*}{ Environmentally engaged } & Yes & & & & 1046 & $11.70 \%$ \\
\hline & No & & & & 7875 & $88.10 \%$ \\
\hline \multirow[t]{3}{*}{ Cluster environm. concern } & Low & & & & 1453 & $16.25 \%$ \\
\hline & Medium & & & & 4005 & $44.80 \%$ \\
\hline & High & & & & 3481 & $38.94 \%$ \\
\hline \multicolumn{7}{|l|}{ Dummies } \\
\hline \multirow[t]{4}{*}{ Residential location } & Farm & & & & 175 & $1.96 \%$ \\
\hline & Village & & & & 2449 & $27.40 \%$ \\
\hline & Suburban & & & & 2141 & $23.95 \%$ \\
\hline & City & & & & 4174 & $46.69 \%$ \\
\hline \multirow[t]{2}{*}{ Gender } & Female & & & & 4407 & $49.30 \%$ \\
\hline & Male & & & & 4532 & $50.70 \%$ \\
\hline \multirow[t]{2}{*}{ Car ownership } & Yes & & & & 7340 & $82.11 \%$ \\
\hline & No & & & & 1500 & $16.78 \%$ \\
\hline \multirow[t]{8}{*}{ Country } & Australia & & & & 650 & $7.27 \%$ \\
\hline & Canada & & & & 634 & $7.09 \%$ \\
\hline & Chile & & & & 932 & $10.43 \%$ \\
\hline & France & & & & 741 & $8.29 \%$ \\
\hline & Israel $^{1}$ & & & & 832 & $9.31 \%$ \\
\hline & Japan & & & & 718 & $8.03 \%$ \\
\hline & Korea & & & & 1014 & $11.34 \%$ \\
\hline & Netherlands & & & & 929 & $10.39 \%$ \\
\hline
\end{tabular}

\footnotetext{
${ }^{1}$ The statistical data for Israel are supplied by and under the responsibility of the relevant Israeli authorities. The use of such data by the OECD is without prejudice to the status of the Golan Heights, East Jerusalem and Israeli settlements in the West Bank under the terms of international law.
} 
ENV/WKP(2014)15

$\begin{array}{lrr}\text { Spain } & 924 & 10.34 \% \\ \text { Sweden } & 647 & 7.24 \% \\ \text { Switzerland } & 918 & 10.27 \%\end{array}$

Note: ${ }^{* * * / * * *}$ indicates significance at the $10 \%\left(^{*}\right) 5 \%\left(^{* *}\right) 1 \%\left(^{* * *}\right)$ level

\section{$1 \quad$ Methodology}

All mode choice models were developed using Binary Logit models. In these models, it is assumed that the household was faced with two alternatives for each mode (walking, cycling, public transport): to use it or not to use it. The alternative of not using a given mode has by definition a utility of zero. The utility of using a given mode $\boldsymbol{i}$ is defined by the following formula:

$$
\begin{gathered}
V_{i}=A S C_{i}+\beta_{\text {SoEc } i} \cdot X_{S o E c}+\beta_{G e o E n v I n f} \cdot X_{G e o E n v I n f}+\beta_{A t i} \cdot X_{A t}+\beta_{\text {Country } i} \\
\cdot X_{\text {Countr }}+\beta_{T T} \cdot X_{T T}\left(1+\varepsilon_{M C} \cdot G_{M C}+\varepsilon_{H C} \cdot G_{H C}\right)
\end{gathered}
$$

$A S C$ refers to the constant specific to each mode. SoEc refers to the parameters being estimated that define the influence of the socio-economic attributes (e.g. age, gender). The attributes of geography, environment and infrastructure (e.g. city, village) are captured by GeoEnvInf. The attitudinal indexes are captured by $A$ and Country is a dummy for the location of the household in a given country.

In the last term, $T T$ stands for travel time. This term captures the effect that travel time has on different sub-groups of the responding households: $G_{\mathrm{MC}}$ being a dummy for the group with medium concern about the environmental condition; and, $\mathrm{G}_{\mathrm{HC}}$ being one for the group with a high concern, value the impact of travel time differently. The parameters $\varepsilon_{\mathrm{MC}}$ and $\varepsilon_{\mathrm{HC}}$ capture these effects in relation to the group of households who state that they have no concern for environmental conditions. If, for example, $\varepsilon_{\mathrm{MC}}$ is zero, that would mean that households with medium concern value travel time exactly the same way as households with no concern at all. Positive values of $\varepsilon$ increase the impact of travel time for the sub-group, negative values decrease it.

This term is only used in the models for the commuting mode and in the car ownership model. The models for the shopping mode do not include a term for travel time, because in this dataset, the only reported travel time is commuting time. The Binary Logit models were estimated using the software BIOGEME (Bierlaire 2003). 
Table 4. Overview of Beta-parameters of binary choice models

\begin{tabular}{|c|c|c|c|c|c|c|c|}
\hline \multirow[b]{2}{*}{$\beta$-Parameter } & \multicolumn{7}{|c|}{ Binary Choice Model } \\
\hline & $\begin{array}{l}\text { Commute } \\
\text { Walk }\end{array}$ & $\begin{array}{l}\text { Shopping } \\
\text { Walk }\end{array}$ & $\begin{array}{l}\text { Commute } \\
\text { Cycling }\end{array}$ & $\begin{array}{l}\text { Shopping } \\
\text { Cycling }\end{array}$ & $\begin{array}{l}\text { Commute } \\
\text { Public Trans }\end{array}$ & $\begin{array}{l}\text { Shopping } \\
\text { Public Trans }\end{array}$ & $\begin{array}{l}\text { Car } \\
\text { Ownership }\end{array}$ \\
\hline Robust pseudo $\mathrm{R}^{2}$ & 0.560 & 0.290 & 0.741 & 0.760 & 0.316 & 0.701 & 0.517 \\
\hline Constant & 0.5 & ${ }^{* * *}-3.290$ & *-1.390 & ${ }^{* * *}-6.070$ & ${ }^{* * *}-1.320$ & ${ }^{* * *}-2.84$ & ${ }^{* * *}-1.060$ \\
\hline \multicolumn{8}{|l|}{ Socio-economic } \\
\hline Income [in $10^{3}$ ] & -0.003 & $\star \star \star \star-0.006$ & -0.002 & ${ }^{\star} 0.003$ & 0.000 & ${ }^{* \star *}-0.014$ & $\star \star \star * 0.040$ \\
\hline $\begin{array}{l}\text { Income Perception } \\
\text { Age }\end{array}$ & ${ }^{\star} 0.086$ & ${ }^{* \star \star} 0.149$ & $\begin{array}{r}0.093 \\
*-0.008\end{array}$ & 0.043 & 0.052 & & $* * * 0.205$ \\
\hline Age $<25$ & -- & -- & & -- & -- & -- & -- \\
\hline Age Group 25-34 & & & & & ${ }^{* * *} 0.680$ & ${ }^{* *} 0.432$ & $* * *-0.777$ \\
\hline Age Group 35-44 & & & & & & & ${ }^{* * *}-0.632$ \\
\hline Age Group 45-55 & & & & & & & ${ }^{* * *}-0.391$ \\
\hline Age Group 55+ & & & & & & & $* * *-0.485$ \\
\hline Education & & & 0.004 & & & & \\
\hline HH Size & & & & & 0.028 & $* * * 0.129$ & $* * * 0.338$ \\
\hline Female & ${ }^{* *} 0.184$ & *0.109 & & 0.030 & $* * * 0.338$ & & \\
\hline No Car & ${ }^{* * *} 0.688$ & $* * * 1.550$ & ${ }^{* \star *} 0.767$ & $* * * 1.380$ & $* * * 1.480$ & $* * * 2.080$ & \\
\hline \multicolumn{8}{|c|}{ Geography, Environment \& Infrastructure } \\
\hline City & ${ }^{* * *} 0.445$ & $* * * 0.633$ & ${ }^{* \star *} 0.114$ & 0.108 & ${ }^{* *} 0.185$ & -0.134 & $* * *-0.430$ \\
\hline Village & ${ }^{* * \star} 0.474$ & & & & $* * *-0.743$ & $\star \star \star *-0.442$ & ${ }^{* \star *} 0.477$ \\
\hline Farm & -0.483 & $* * \star-1.680$ & & & $* * *-1.050$ & & \\
\hline Travel Time & $* \star *-0.057$ & & $* * \star-0.070$ & & $* * * 0.050$ & & * -0.007 \\
\hline Commute & & & & & & & \\
\hline - medium & -0.040 & & -0.041 & & -0.016 & & 0.015 \\
\hline concerned & & & & & & & \\
\hline $\begin{array}{l}\text { - highly } \\
\text { concerned }\end{array}$ & ${ }^{* *}-0.099$ & & *-0.094 & & -0.026 & & 0.076 \\
\hline $\begin{array}{l}\text { TT Savings with } \\
\text { Car }\end{array}$ & *** -0.436 & & $* * *-0.390$ & & $* \star *-0.426$ & & $* \star 0.383$ \\
\hline TT to PT station & 0.006 & -0.007 & $\star \star \star * 0.023$ & & *** -0.048 & -0.006 & $* * * 0.035$ \\
\hline \multicolumn{8}{|l|}{ Attitudinal } \\
\hline $\begin{array}{l}\text { Environmental } \\
\text { Index } 1\end{array}$ & -0.065 & ${ }^{\star *} 0.050$ & & -0.040 & 0.036 & & \\
\hline $\begin{array}{l}\text { Environmental } \\
\text { Index } 2\end{array}$ & & & & 0.125 & $* * * 0.163$ & & $* * *-0.246$ \\
\hline $\begin{array}{l}\text { Supporting } \\
\text { environmental org. }\end{array}$ & & & & $* * * 0.552$ & & $* * * 0.502$ & \\
\hline $\begin{array}{l}\text { Local Environment } \\
\text { Index }\end{array}$ & & $* * *-0.070$ & & -0.070 & & 0.073 & \\
\hline Env. Policy Index & & ${ }^{* *} 0.050$ & & & & & \\
\hline \multicolumn{8}{|c|}{ Country (Base = Australia) } \\
\hline Canada & 0.331 & -0.224 & -0.398 & 1.030 & -0.133 & 0.341 & -0.492 \\
\hline Chile & 0.191 & 0.297 & 0.512 & 1.390 & ${ }^{* *} 0.399$ & 0.114 & -0.746 \\
\hline France & ${ }^{* *} 0.636$ & ${ }^{* *} 0.466$ & 0.730 & 1.130 & 0.284 & $* *-0.773$ & 0.031 \\
\hline Israel & -0.022 & -0.117 & -0.223 & 1.170 & -0.277 & ${ }^{*}-0.514$ & -0.233 \\
\hline Japan & ${ }^{* *} 0.638$ & 0.219 & $\star \star \star 2.350$ & $* * * 4.530$ & -0.047 & $\star \star *-1.57$ & -1.590 \\
\hline Korea & $* * * 0.839$ & $* * * 1.400$ & 0.070 & *1.980 & *0.308 & -0.23 & 0.035 \\
\hline Netherlands & -0.527 & ${ }^{* *} 0.461$ & $\star * \star 3.260$ & $* * * 5.020$ & ${ }^{* * *}-0.730$ & $* * *-2.57$ & -0.751 \\
\hline Spain & $* * 1.430$ & $* * * 1.740$ & 0.070 & 0.897 & -0.015 & $* * *-0.869$ & 0.630 \\
\hline Switzerland & 0.303 & ${ }^{* * *} 0.950$ & $\star \star \star 1.250$ & ***2.970 & $* * * 0.623$ & ${ }^{* * *} 0.675$ & -1.740 \\
\hline Sweden & ${ }^{* * *} 0.869$ & ${ }^{\star * \star} 0.652$ & $\star * * 1.810$ & $* * * 3$ & & & \\
\hline
\end{tabular}

Note: Beta parameter shows influence of the variable on choosing the mode. Positive parameter means variable increases probability of mode being chosen. ${ }^{* * *} /{ }^{* * *}$ indicates significance at the $10 \%\left({ }^{*}\right) 5 \%\left({ }^{* *}\right) 1 \%\left({ }^{* * *}\right)$ level 
This model estimates the influence of household attributes on the decision to walk as a commuting mode. The model results indicate that long commuting distances, and a greater time expenditure relative to driving strongly discourages people from walking. However, travel time has a smaller impact on households in the sub-group of respondents who are highly-concerned about the environment. This is shown by the negative $\varepsilon$-parameters for the sub-groups of moderately and highly concerned households, although the difference from households that are moderately concerned is not statistically significant.

Not owning a car also has a positive impact on walking, as does living in a city or a town. Having a higher income and being environmentally friendly have a negative influence on walking, but the influences are very small and not statistically significant. All other differences are captured by country dummies. Households in Spain, Sweden, Korea, Japan and France are more likely to walk to work than the other countries in the survey.

Running the model for each country separately shows other interesting differences. Sweden is the only country with a substantial impact of the environmental index, meaning that only in Sweden do people walk to work due (in part) to attitudes towards the environment. In France, the distance to the next public transport station is important, but travel time savings by car is not at all, indicating that in France public transport is widely seen as a valuable substitute for driving. Israel is the only country where income has an impact of the same magnitude as commuting time. This could suggest that either walking has a "poor man" stigma, or perhaps that the infrastructure in affluent residential areas deters people from walking to work.

Figure 1. Utility impact in model for commuting by foot

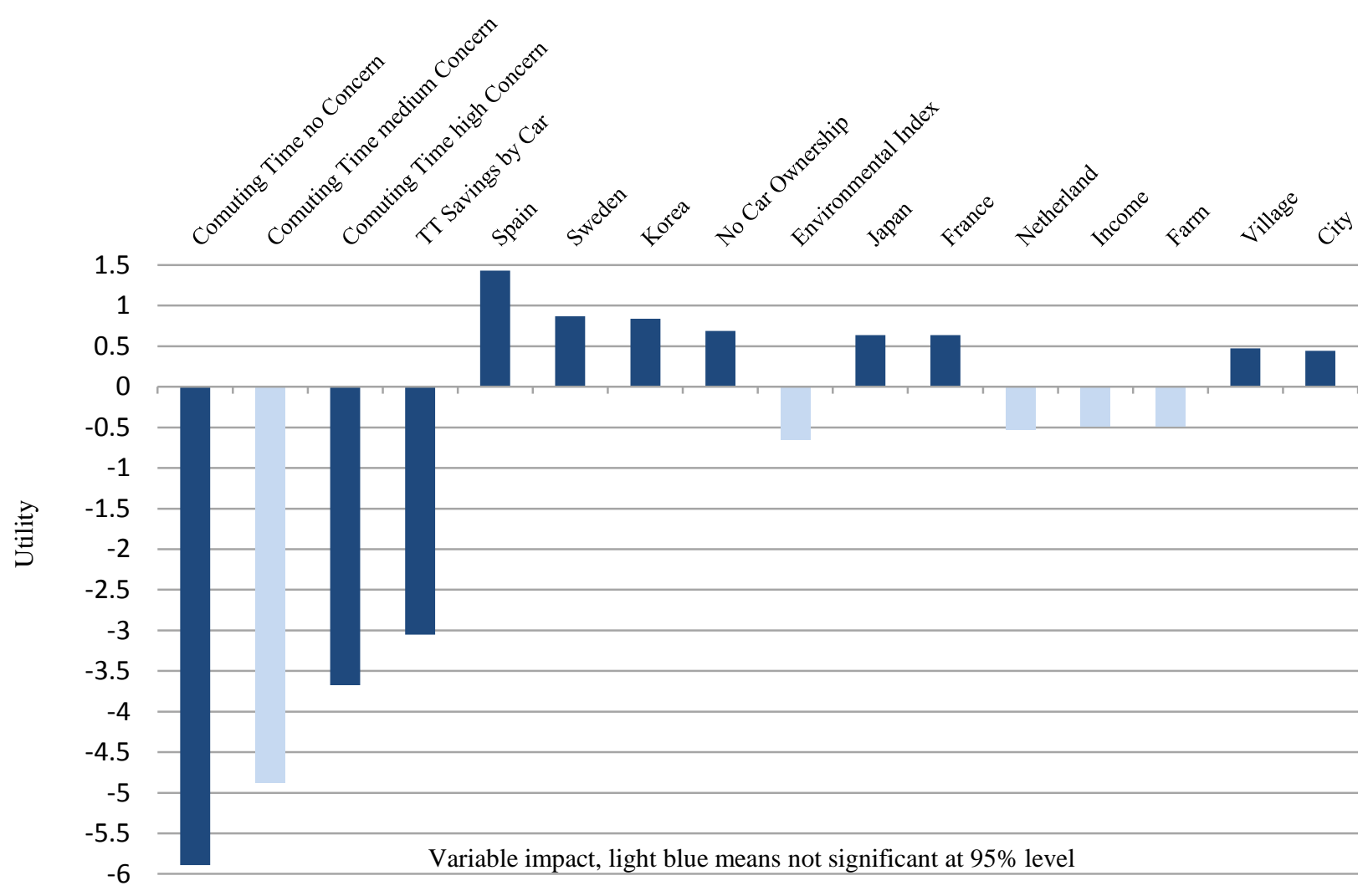


This model estimates the influence of household attributes on the decision to walk as a mode for going shopping. The biggest impact on the decision to walk comes from the negative constant. This result certainly reflects the fact that many people do not wish to go shopping on foot because one must live very near the shops to be able carry home one's own purchases. This makes the distances for which walking is a valuable alternative much shorter for shopping than for commuting.

Households that do not own a car are more likely to shop by foot, as are those who live in a city, have a lower (perceived) income and are more environmentally friendly. However, these impacts are relatively minor, probably because they only apply when shopping facilities are located within reasonable distances.

In Spain, Korea, Switzerland, Sweden, France and the Netherlands, people are more likely to go shopping on foot. In Chile, France, Israel and Korea, income and car ownership have a greater negative impact, perhaps reflecting a spatial pattern of shopping infrastructure which is more car-dependent in areas with higher average incomes. In Japan and Sweden, car ownership and public transport accessibility are important. In the Netherlands, income and environmental concerns are the main determinants for the choice.

\section{Figure 2. Utility impact in model for shopping by foot}



4

Model for commuting by bicycle

This model estimates the influence of household attributes on the decision to cycle as the transport mode for the daily commute. Commuting travel time has the biggest impact on the decision to cycle to work. The parameter is strongly negative, meaning that the longer the commute, the less likely it is that 
people will cycle to work. This is understandable given the low speed and high physical demands of cycling. However, travel time has a smaller impact in households belonging to the environmentally concerned sub-group. The difference with households that are moderately concerned is not statistically significant, but still has a relatively big impact on average.

Cycling is at a great disadvantage to driving in terms of travel time, making it a less likely choice of transport. Households without a car and with poor accessibility to public transport are more likely to use the cycling mode. Socio-economic variables such as income, age and gender have no significant influence on the decision to cycle to work.

Differences among countries have a large impact, as the large positive parameters for the Netherlands, Japan and Sweden indicate. Households in these countries are much more likely to commute by bicycle than other countries. The Netherlands, famous for its cycling tradition, has the advantage of being flat and having an excellent network of cycling paths. But there is also a significant and positive impact on this mode for Swiss respondents.

In Australia, public transport accessibility and car ownership have the greatest impact. In Chile, income has a higher than average impact. Israel has a very strong negative constant for cycling, but also a strong positive impact of environmental concerns towards cycling. In Japan, age has a strong negative impact. In Korea, the main impact in the model for cycling to work is lower income. Spain too has a strong impact of lower income on cycling to work.

Figure 3. Utility impact in model for commuting by bicycle

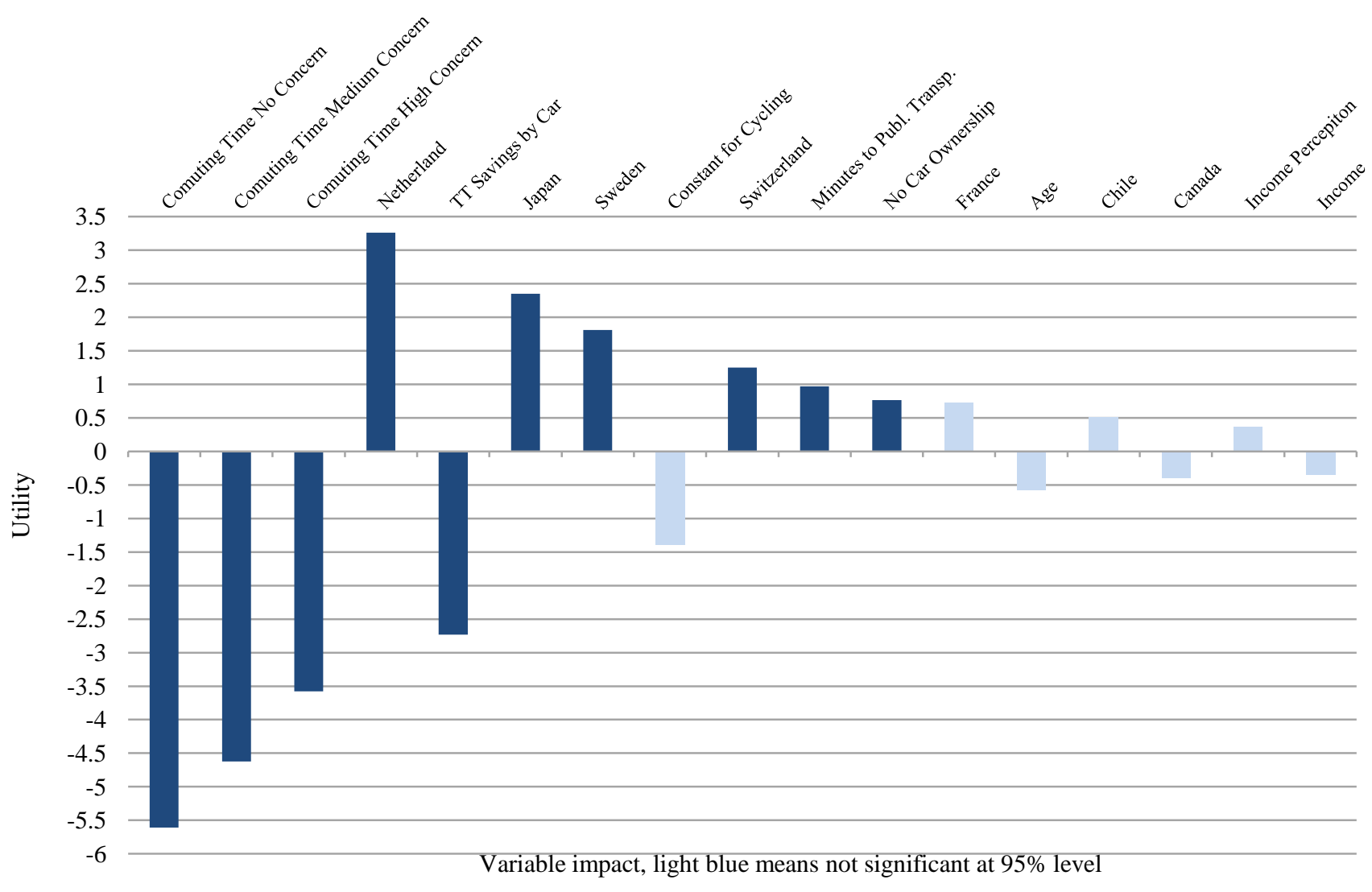


The very strong negative constant of shopping by bicycle indicates that cycling is generally the least preferred mode of transport for shopping. This is understandable, as in most cases it is difficult to carry cumbersome packages on a bicycle. Whether it is suitable to shop by bicycle is not only directly a question of distance between shopping facility and home, but also of the amount of goods purchased on an average shopping trip, which is of course a function of frequency. It is also (indirectly) related to the distance between shopping facility and home.

\section{Figure 4. Utility impact in model for shopping by bicycle}

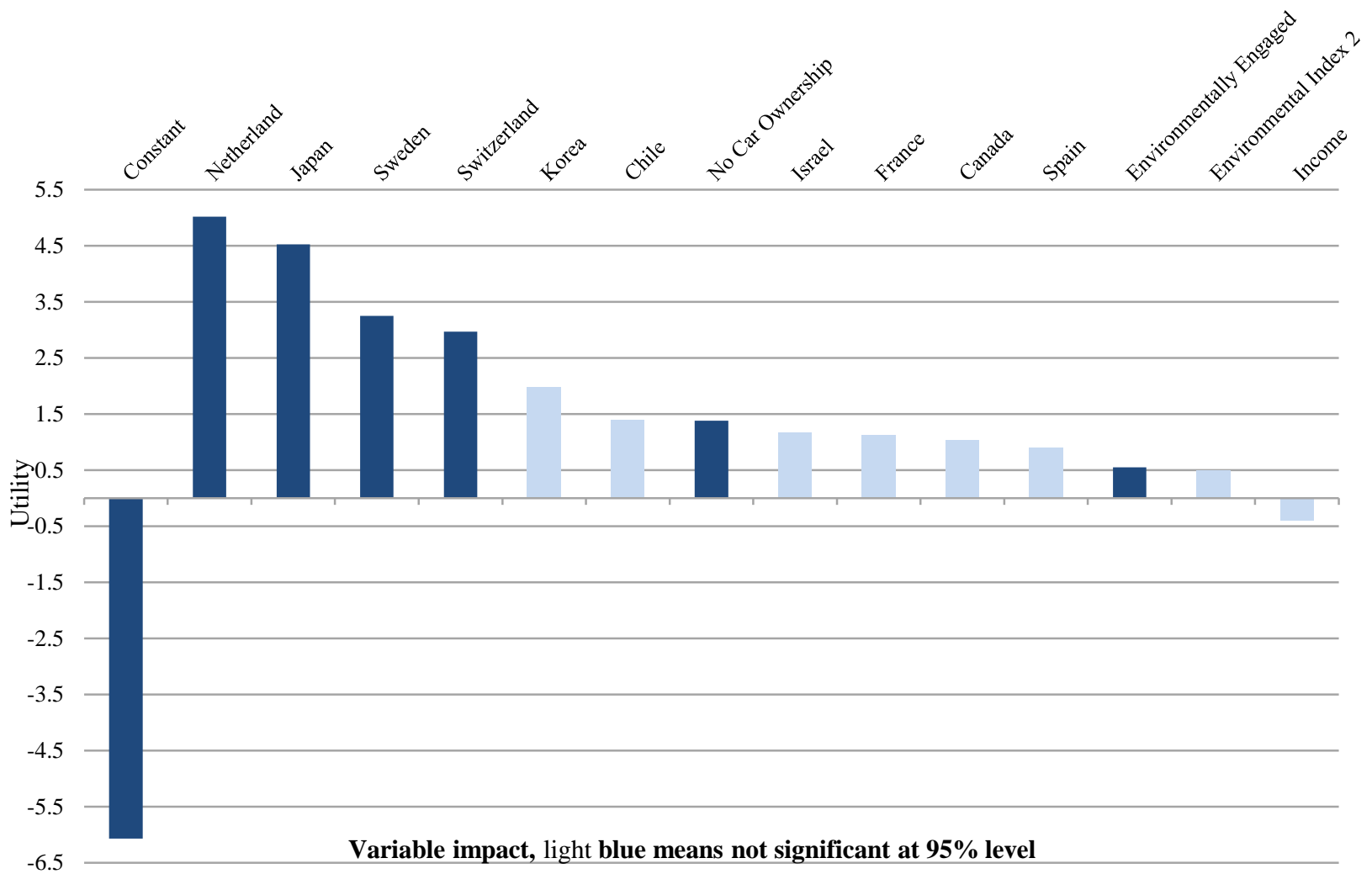

Households which do not have cars are more likely to shop by bicycle, and being environmentally friendly has a very small positive impact as well. However, whether households use cycling as a mode choice for shopping is mostly determined by the country in which the household is located. Being located in the Netherlands, Japan, Sweden and Switzerland has a strong positive impact on using this mode. Other countries also have a positive parameter (compared to Australia, which is the baseline alternative in the model) but which are not statistically significant. Again, socio-economic variables have no influence on the decision.

Model for commuting by public transport

This model estimates the influence of household attributes on the decision to use public transport as the mode for the daily commute. The biggest impact comes from travel time. The higher the commuting time (or the greater the distance between workplace and home), the more likely people are to use public transport. An almost equally big impact comes from the travel time disadvantage relative to driving by car. The greater the relative time disadvantage public transport incurs, the less likely households are to use 
public transport. An interaction between travel time and environmental concern is not significant, as travel time has the same impact for all three sub-groups (no concern, medium concern and high concern). This is in contrast to alternative modes like walking and cycling.

Figure 5. Utility impact in model for commuting by public transport

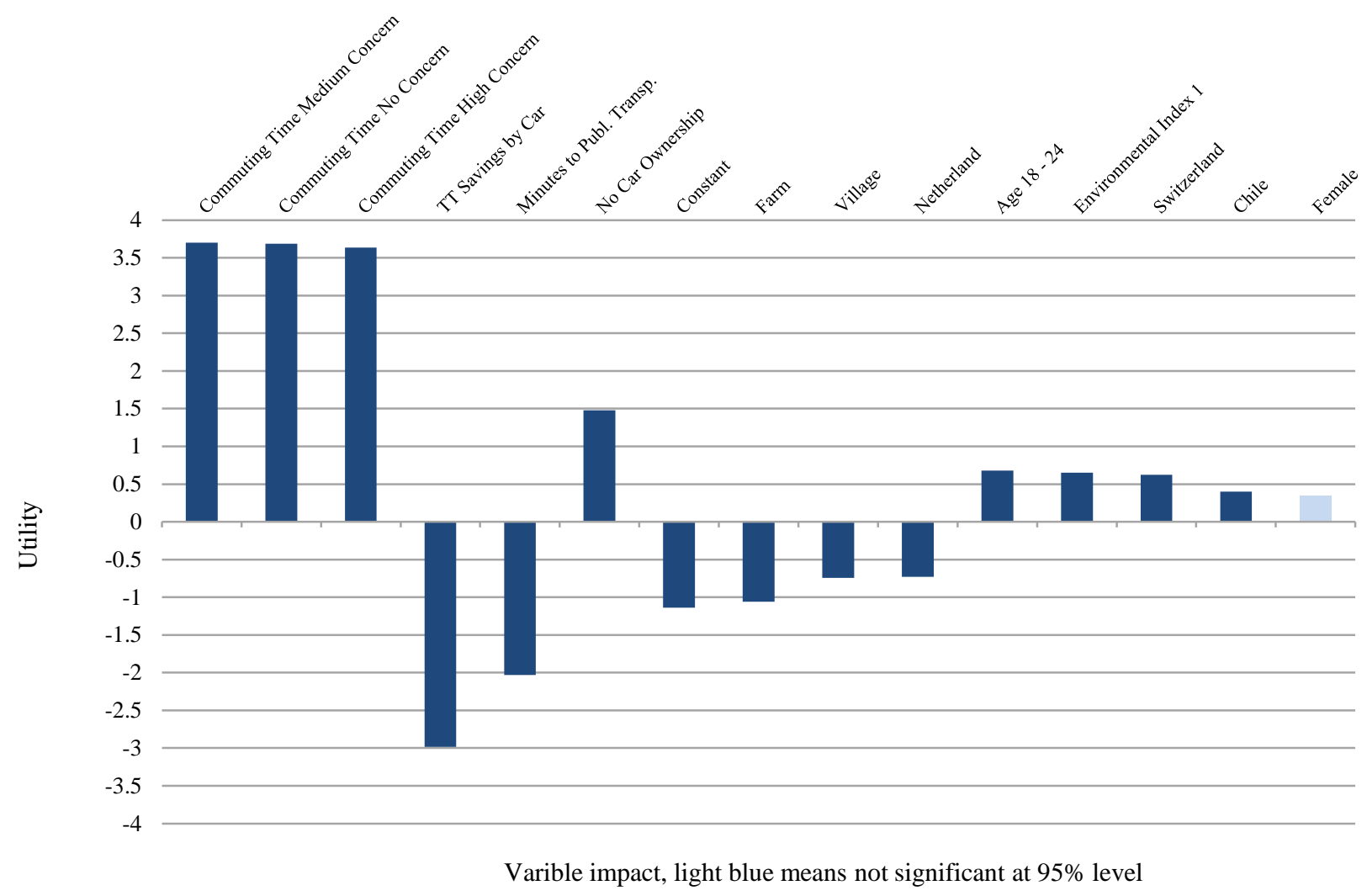

The next biggest impact on the decision comes from the relative availability of public transport compared with car use, captured by the variables reflecting accessibility of public transport and car ownership: The nearer the next public transport stop and the less available the car, the more likely people are to use public transport. The negative influence of residential location on a farm or a village is similar. .

Objective factors such as travel time and availability dominate the decision. Personal preferences like environmental friendliness, and socio-economic variables like age or income, only play a marginal role. Also, differences between countries are rather insubstantial. Being located in the Netherlands has a negative effect, being located in Switzerland or Chile has a positive and statistically significant impact. Differences among countries show that in Chile, income has by far the greatest (negative) impact on public transport use. In Japan, travel time savings by car have no influence. The only countries with a substantial (positive) impact of environmental concerns on use of public transport are Switzerland and Sweden.

\section{Model for shopping by public transport}

This model estimates the influence of household attributes on the decision to use public transport for shopping. Similar to the other two shopping models, the negative constant is high, meaning there is a very strong preference among households to use the car for shopping, regardless of other attributes. Income has, contrary to the models for other modes, a great impact. This, together with the impact of car ownership, implies that households with a car prefer the car for shopping, and the higher a household's income, the 
stronger this preference is. People who are engaged in helping the environment are a bit more likely to use public transport for shopping. Household size has a somewhat positive impact. One possible reason could be, that in bigger households it is more likely that the car is used by another member of the household for another purpose and therefore shopping is done by public transport.

The country in which the household is located has a great impact on the decision. Households in the Netherlands, Japan, Spain and France are much less likely to shop using public transport. This cannot be explained by a lack of public transport infrastructure, since Japan, France and the Netherlands have extensive public transport systems. Instead, a combination of shop size, distribution, and accessibility may play an important role. Residing in Switzerland has a substantial positive impact on shopping by public transport.

Figure 6. Utility impact in model for shopping by public transport

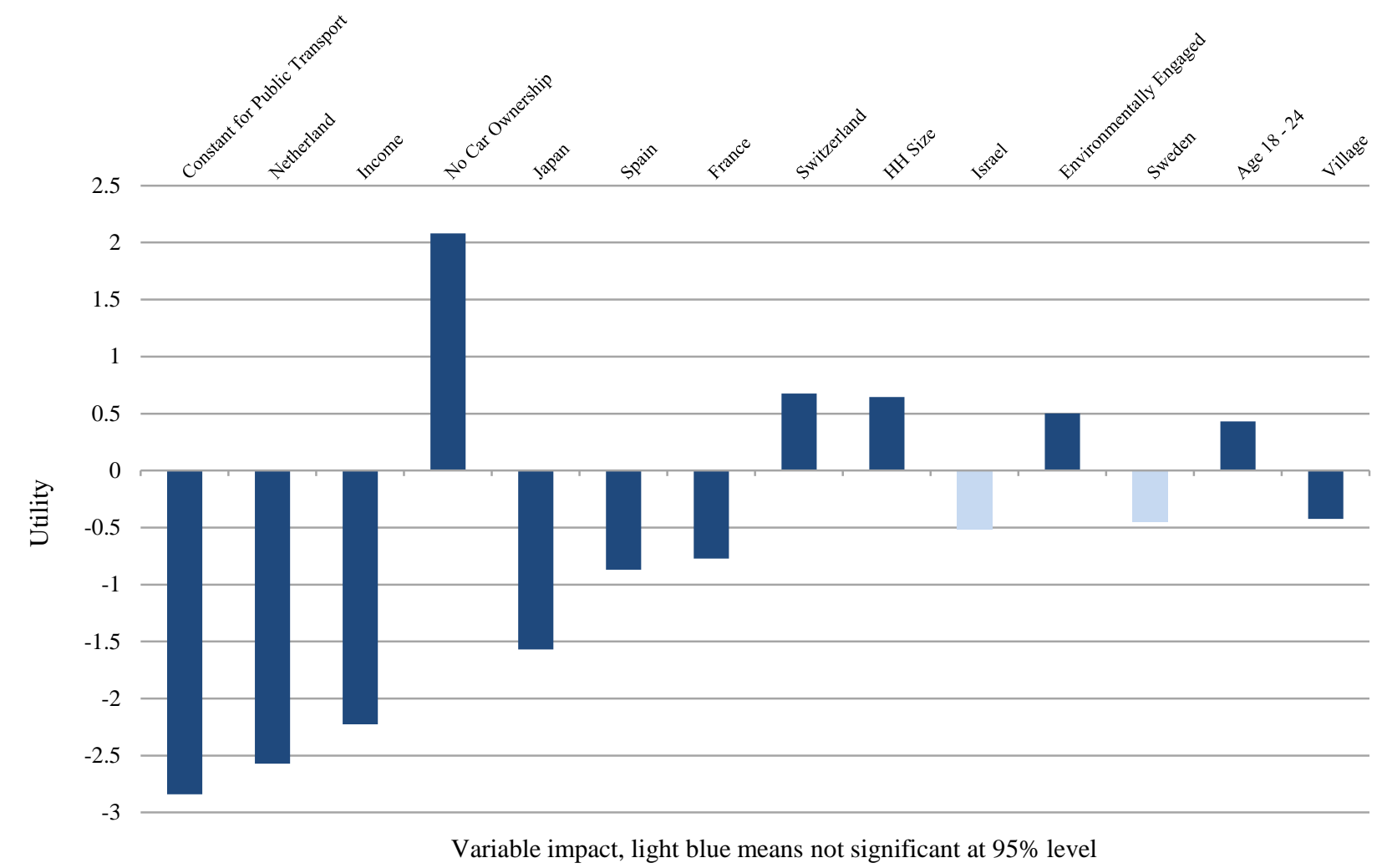

Car-ownership model

As we have seen in the six models about alternative mode choices, the lack of car ownership has a significant impact on the choices for alternative modes, especially for shopping purposes. Because of this, a car ownership model was estimated, to support the findings of the other six models.

By far the biggest impact on car ownership comes from income. With cultural and economic differences among countries captured by the country-dummies, the parameter estimated for income clearly shows the strong impact of absolute household income on car ownership. The higher the household income, the more likely it is that the household owns a car. The coefficient for the impact of income is almost two and a half times greater than the impact of travel time savings by car. Understandably, the 
bigger the advantage in travel time of the car mode relative to other modes, the more likely the household is to own a car.

Household size also has a substantial impact, as larger families and those with children have a greater need for a car. The impact of household size is about the same as the one of public transport accessibility. Being further away from a public transport stop promotes car ownership.

Interestingly, even in the car ownership model, being environmentally friendly has a minor impact, decreasing the probability of car ownership only slightly. Other variables with a small, but statistically significant impact are being younger, living in a city (both negative), and living in a village (positive).

Country-dummies have a substantial influence: all country-dummies except for Spain are negative, meaning that even when controlling for other factors these countries have a lower probability for car ownership than Australia, which is the reference country. The countries with the greatest negative impact are Switzerland and Japan, followed by Sweden, the Netherlands and Chile.

Switzerland and Japan are the two countries with by far the highest public transport usage, measured in person-kilometre per capita. This supports the hypothesis that well established public transport systems have the potential to decrease car ownership.

Differences among countries are: in Australia, living in a village (as distinct from a city) has an overwhelmingly strong (positive) impact on car ownership. In Chile, Israel, Korea and the Netherlands, car ownership is almost solely determined by income. In France, the two strongest determents by far are household size and environmental attitudes. In Japan, household size has the biggest impact. In Spain, the biggest impact comes from reported distance to the public transport system.

Figure 7. Utility impact in car ownership model (part I)

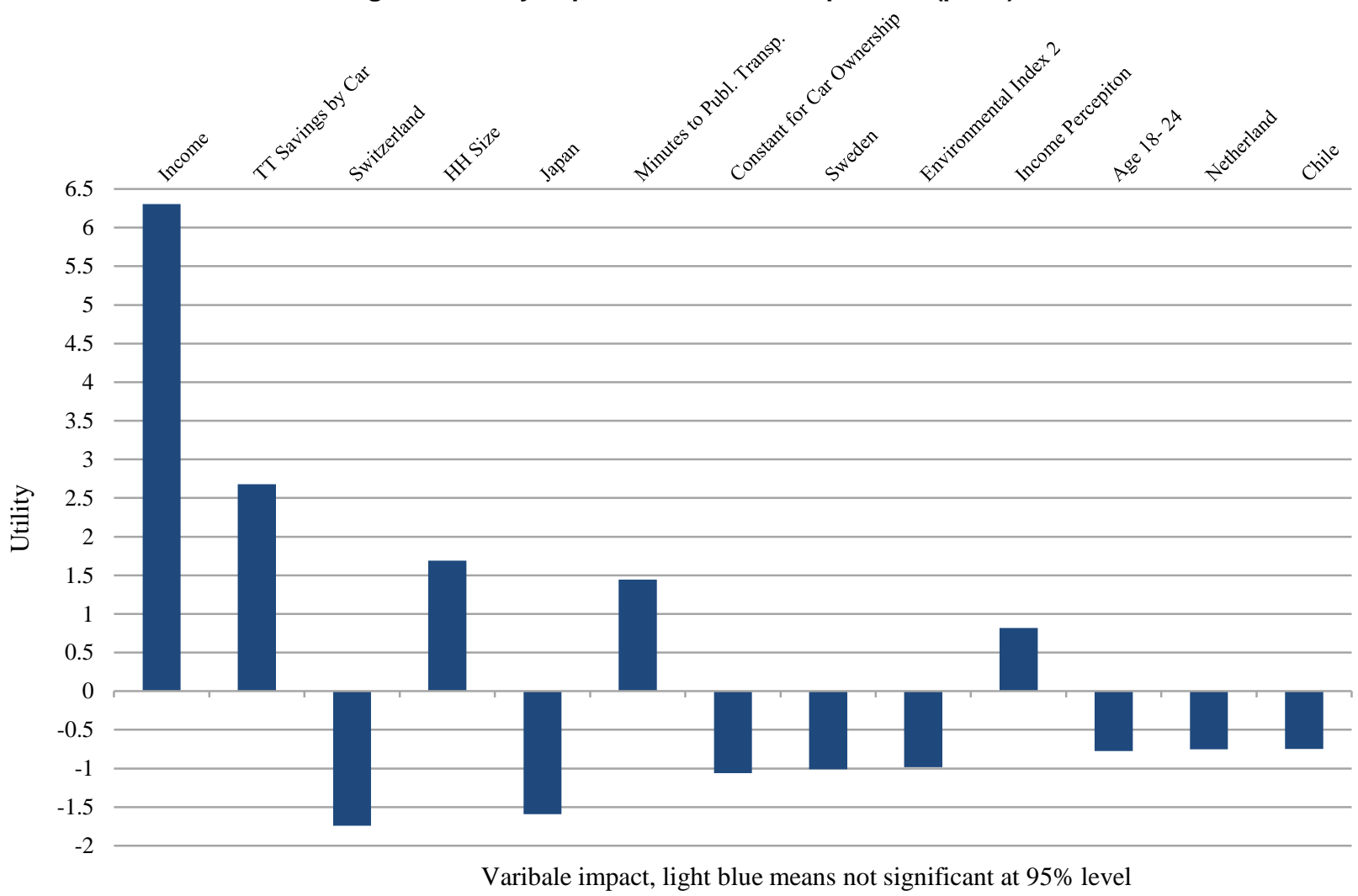


ENV/WKP(2014)15

Figure 8. Utility impact in car ownership model (part II)

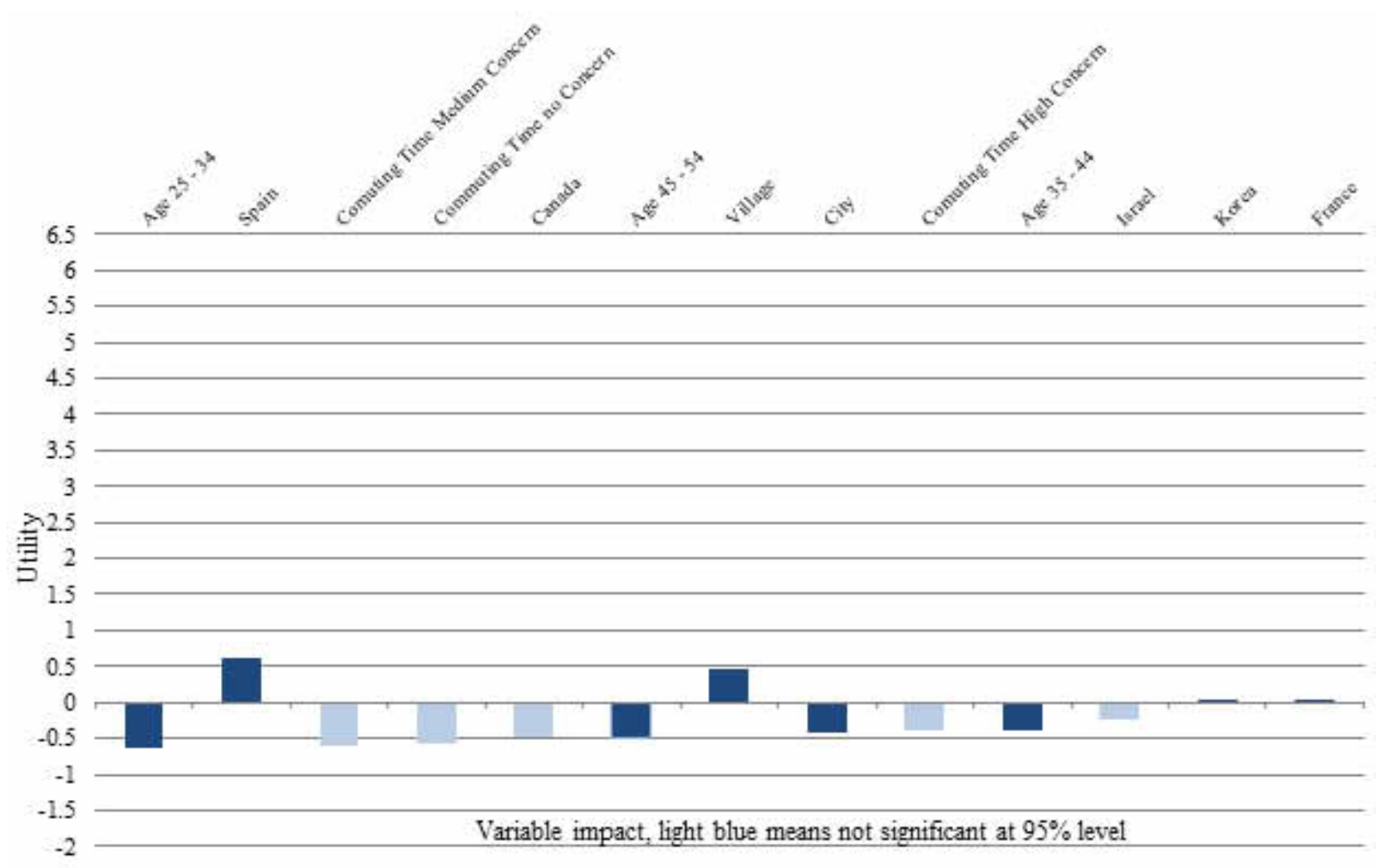




\section{WILLINGNESS-TO-PAY A PREMIUM FOR AN ELECTRIC CAR}

This section presents the results related to respondents' willingness-to-pay (WTP) more for the purchase of an electric vehicle. The number of cases differs widely between countries: The Netherlands contributed 302 respondents to the sample whereas the French data included 786 cases.

Figure 9. WTP price premium among countries sort by median

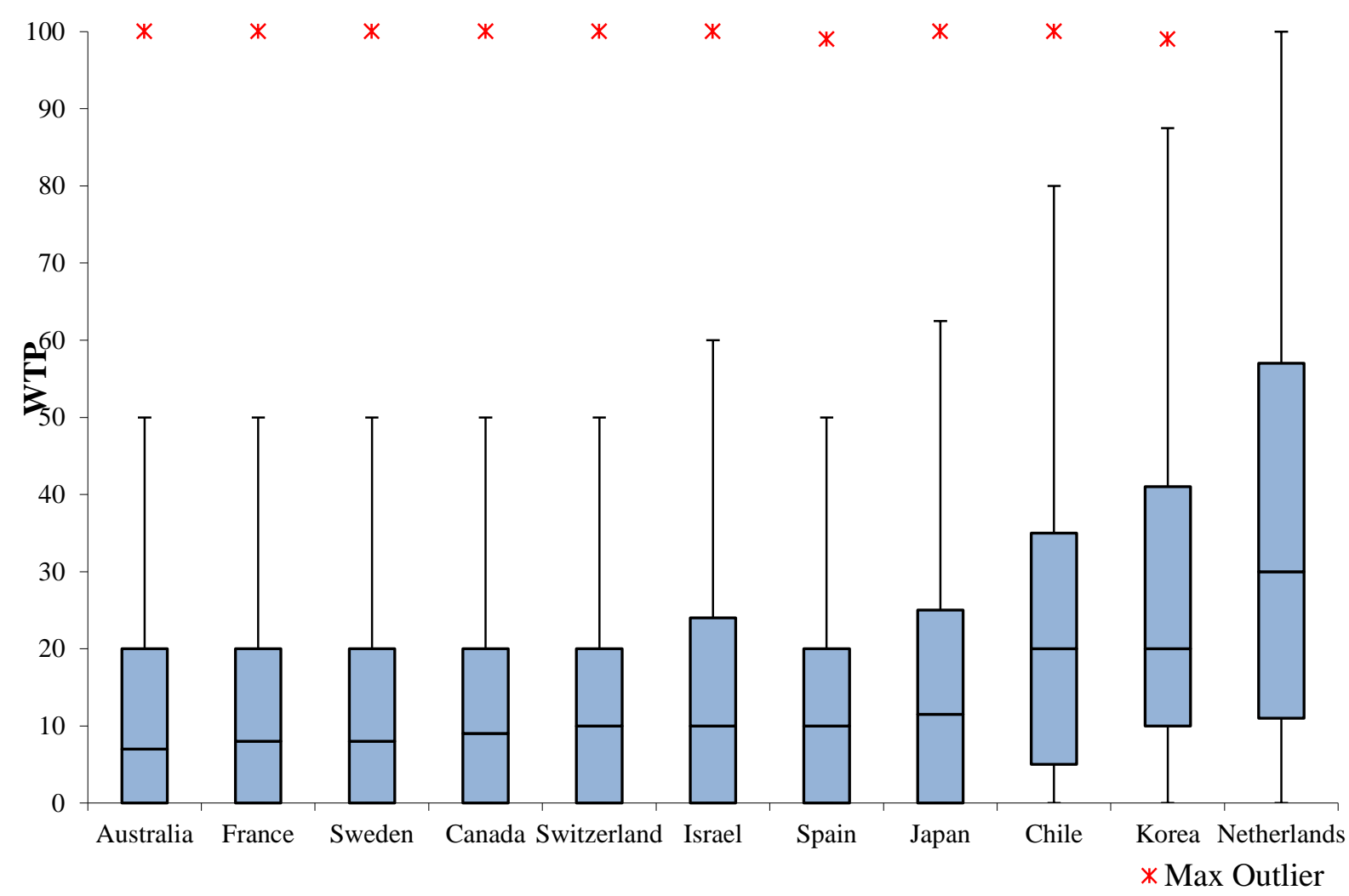

Note: The shaded bar in this boxplot indicates the lower (25\% of respondents gave at least this WTP) and upper (75\% of respondents) quartiles, while the line in the box indicates the median (50\% of respondents). Max outliers are all 100 , meaning that in all countries, there was at least one respondent that gave a WTP of $100 \%$.

Figure 9 gives a first glance at the differences in WTP across countries. Apparently, respondents from the Netherlands are willing to pay the highest additional amount to purchase an electric vehicle. Participants from France are most reluctant to pay an additional amount. With the exception of Chile, Korea and the Netherlands, countries are not willing to pay more than $20 \%$ extra for an electric car, on average.

Table 5 shows the mean WTPs among different socioeconomic categories of the dataset whose significant influences are estimated in the Censored Regression model. There seems to be no major differences in WTP between male and female respondents. Among age groups, only the mean WTP of those over the age of 55 deviates notably from other age groups. It is evident that respondents not participating in the labour market - unemployed, pensioners, those unable to work - are less likely to pay a premium price for an electric car.

The distribution of WTP related to household size $^{2}$ and income does not have a clear direction. Respondents' place of residence shows a clear orientation. People who live in major towns or cities are

\footnotetext{
${ }^{2}$ This may be due to the relatively small number in the cell.
} 
more likely to pay extra for an environmentally friendly car than people who live in rural areas. The mean values of WTP decrease with household size.

Table 5. Overview of mean WTP and socio-economic variables

\begin{tabular}{|c|c|c|c|c|}
\hline & Category & Mean & Std. Deviation & Per cent \\
\hline Total & & 20.41 & 22.00 & $100.0 \%$ \\
\hline \multirow[t]{2}{*}{ Gender } & Male & 20.75 & 22.55 & $58.4 \%$ \\
\hline & Female & 19.95 & 21.23 & $41.6 \%$ \\
\hline Age & $18-24$ & 21.25 & 20.95 & $14.8 \%$ \\
\hline \multirow[t]{4}{*}{ group } & $25-34$ & 20.44 & 22.01 & $22.5 \%$ \\
\hline & $35-44$ & 20.97 & 22.58 & $25.4 \%$ \\
\hline & $45-54$ & 21.37 & 22.68 & $22.3 \%$ \\
\hline & $55+$ & 17.71 & 20.91 & $15.0 \%$ \\
\hline \multirow{9}{*}{$\begin{array}{l}\text { Education } \\
\text { (Years post high } \\
\text { school) }\end{array}$} & 0 & 17.68 & 21.37 & $16.0 \%$ \\
\hline & 1 & 16.90 & 19.56 & $5.5 \%$ \\
\hline & 2 & 19.85 & 21.25 & $15.7 \%$ \\
\hline & 3 & 18.02 & 19.97 & $9.0 \%$ \\
\hline & 4 & 24.37 & 22.63 & $29.2 \%$ \\
\hline & 5 & 16.77 & 20.02 & $6.8 \%$ \\
\hline & 6 & 23.12 & 24.81 & $6.7 \%$ \\
\hline & 7 & 23.41 & 24.66 & $3.6 \%$ \\
\hline & 8 & 22.59 & 23.77 & $7.5 \%$ \\
\hline \multicolumn{5}{|c|}{ Mean WTP and socio-economic variables } \\
\hline \multirow{8}{*}{$\begin{array}{l}\text { Employment } \\
\text { status }\end{array}$} & Self employed & 23.93 & 24.63 & $13.6 \%$ \\
\hline & Employee & 20.50 & 21.84 & $56.5 \%$ \\
\hline & Retired & 15.13 & 19.56 & $5.0 \%$ \\
\hline & Homemaker & 21.62 & 21.84 & $8.5 \%$ \\
\hline & Unemployed & 15.28 & 20.71 & $4.1 \%$ \\
\hline & Student & 21.13 & 19.68 & $9.3 \%$ \\
\hline & Unable to work & 18.49 & 24.97 & $1.5 \%$ \\
\hline & Other & 24.02 & 24.70 & $1.5 \%$ \\
\hline Household & 1 & 16.85 & 21.10 & $11.3 \%$ \\
\hline \multirow[t]{5}{*}{ size } & 2 & 17.43 & 20.46 & $26.1 \%$ \\
\hline & 3 & 20.51 & 22.23 & $23.7 \%$ \\
\hline & 4 & 23.88 & 23.04 & $27.3 \%$ \\
\hline & 5 & 14.76 & 18.98 & $3.9 \%$ \\
\hline & 6 & 25.41 & 21.37 & $7.7 \%$ \\
\hline Income & $<24 ' 200$ & 18.36 & 22.68 & $6.7 \%$ \\
\hline \multirow[t]{11}{*}{ (in USD) } & 24'201-34'400 & 20.49 & 21.63 & $8.6 \%$ \\
\hline & 34'301-41'800 & 20.12 & 23.40 & $8.5 \%$ \\
\hline & $41 ' 801-49 ' 000$ & 20.13 & 22.95 & $8.6 \%$ \\
\hline & 49'001-56'700 & 19.44 & 20.31 & $8.6 \%$ \\
\hline & $56 ' 701-65 ' 200$ & 21.10 & 20.42 & $9.8 \%$ \\
\hline & $65^{\prime} 201-75^{\prime} 200$ & 21.11 & 21.90 & $10.6 \%$ \\
\hline & 75'201-88'800 & 20.76 & 20.72 & $10.3 \%$ \\
\hline & $88 ' 801-127^{\prime} 000$ & 21.78 & 21.75 & $13.9 \%$ \\
\hline & $>127^{\prime} 000$ & 21.36 & 22.74 & $7.0 \%$ \\
\hline & Don't know & 19.89 & 22.17 & $2.8 \%$ \\
\hline & Prefer not to answer & 18.16 & 25.00 & $4.5 \%$ \\
\hline
\end{tabular}




\begin{tabular}{|c|c|c|c|c|}
\hline \multirow[t]{4}{*}{ Area } & Major town/city & 23.72 & 22.68 & $56.7 \%$ \\
\hline & Suburban & 19.67 & 21.94 & $22.6 \%$ \\
\hline & Small town or village & 15.41 & 19.66 & $19.1 \%$ \\
\hline & Isolated dwelling & 13.26 & 19.49 & $1.6 \%$ \\
\hline
\end{tabular}

The unit of the WTP variable is per cent, the range is zero to one hundred, where one hundred per cent corresponds to double the price of an average car. This means that the data is censored. The appropriate model to estimate the influence for censored data is a Tobit model. The Censored Regression model used is described in the next section and the estimated Censored Regression parameters and marginal effects are shown in Table 6.

The following section contains the findings of the estimated model. Afterwards the results for socioeconomic, environmental, policy and country impacts are discussed to identify differences on a geographical and cultural basis.

\section{$1 \quad$ Methodology}

As seen in Figure 10, WTP data is censored on both sides as the respondents are not given the option to say if they would pay more than double for an electric car (right censoring at 100) or if they would even pay less (left censoring at zero) than for a typical vehicle.

Figure 10. Histogram WTP as a price premium for an electric car

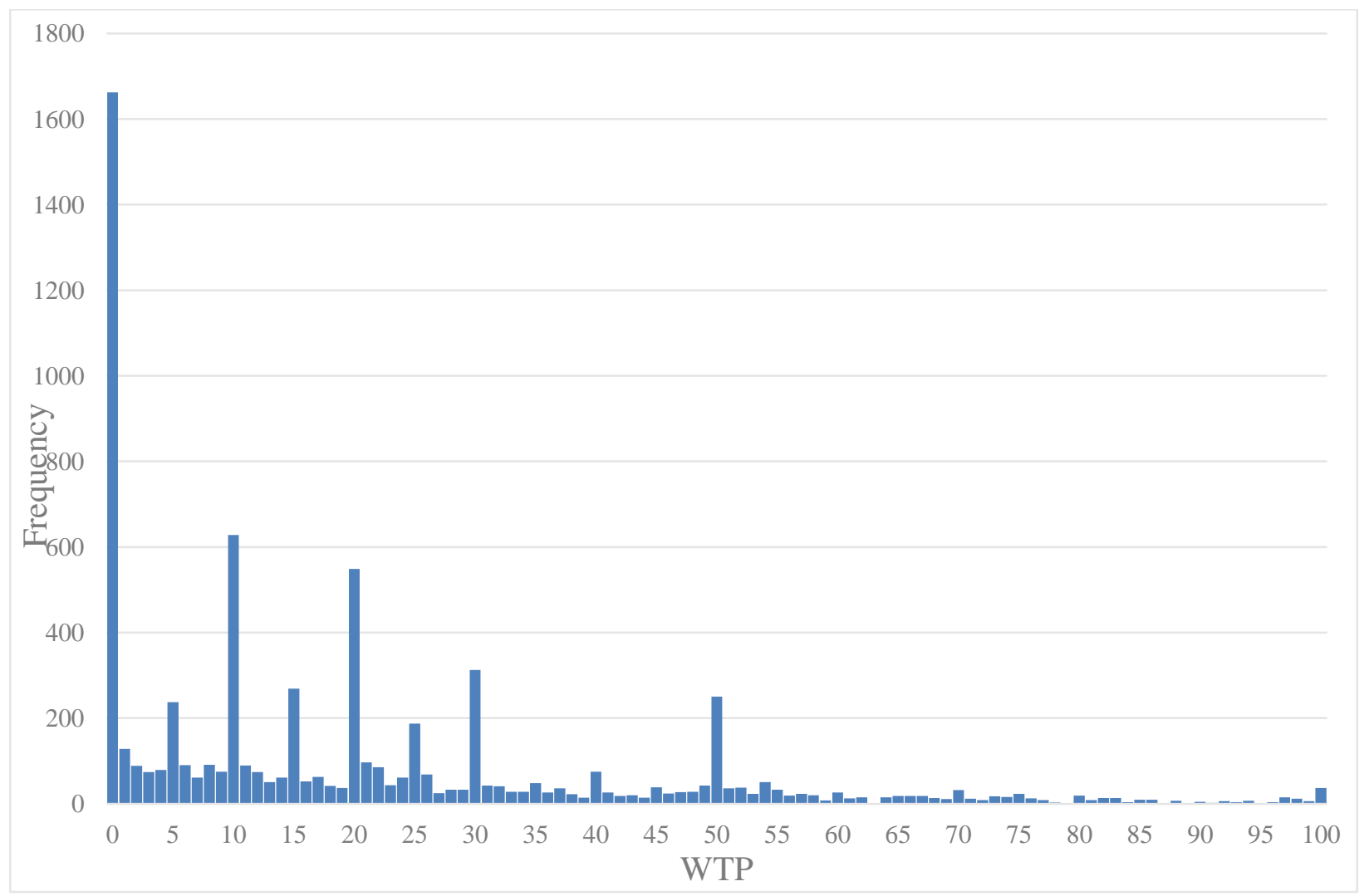

The Censored Regression model used in this approach is a more generalized form of the Tobit model as it can be estimated both with a left and a right censored dependent variable. The regression function can be written as: 


$$
\begin{gathered}
y_{i}^{*}=\alpha+\beta_{-}(\text {SoEc } i) \cdot X_{-} \operatorname{SoE} c+\beta_{-}(\text {At } i) \cdot X_{-} A t+\beta_{-}(\text {Country } i) \cdot X_{-} \text {Countr }+\varepsilon_{i} \\
y_{i}= \begin{cases}0 & \text { if } y_{i}^{*} \leq 0 \\
y^{*} & \text { if } 0<y_{i}^{*}<100 \\
100 & \text { if } y_{i}^{*} \geq 100\end{cases}
\end{gathered}
$$

As previously, $\alpha$ stands for the constant, SoEc for the socio economic, At for attitudinal and Country for country variables and betas. The model is estimated by the Maximum Likelihood Method as the OLS would lead to an underestimation of the coefficients. The estimated betas of a Censored Regression model reflect only the effects of the independent variables on the latent variable $y^{*}$ (Green 2003):

$$
\frac{\partial E\left[y^{*}\right]}{\partial x_{i}}=\beta_{i}
$$

This means that the betas only show the impact on people who are willing to pay a higher price for an electric car. But it is interesting to identify the effects of the independent variables on the general WTP. Hence the calculation of the marginal effect of the variables on $y$ (ibid.):

$$
\frac{\partial E[y]}{\partial x_{i}}=\Phi\left(\frac{X_{i} \beta}{\sigma}\right) \beta_{i}
$$

As the number of children correlates strongly with household size, that variable was deleted from the final model. Finally, several attitudinal variables correlating amongst one another (for example environmental attitude index) were removed as well. The gender and the area type variables showed no significant effect in any model so they were not applied to the model. Region inhabited showed no significant effect on the WTP either. Following OECD (2014), an aggregated variable based on age and employment status was applied to the model to obtain an indication of the interactions of the two effects. Additionally, a variable on the number of alternative-fuelled vehicles in a household was created. Table 6 shows the estimated coefficients. 
Table 6. Overview of $\beta$-parameters of WTP models

\begin{tabular}{|c|c|c|c|c|c|c|}
\hline & $\beta$ & Std. Error & $\mathbf{z}$ & $p$-value & & $d y / d x$ \\
\hline Constant & -12.55 & 2.65 & -4.73 & 0.00 & $* * *$ & \\
\hline \multicolumn{7}{|l|}{ Socio-economic } \\
\hline Household size & 0.77 & 0.26 & 2.92 & 0.00 & $* \star \star$ & 0.62 \\
\hline Income & 4.46E-06 & $1.63 E-05$ & 0.27 & 0.78 & & $3.62 E-06$ \\
\hline Students $<30$ years & -- & -- & -- & -- & & -- \\
\hline Working adults $<45$. & -1.89 & 1.16 & -1.63 & 0.10 & & -1.53 \\
\hline Working adults $>45$. & -1.24 & 1.27 & -0.98 & 0.33 & & -1.01 \\
\hline Homemakers : & -4.56 & 1.66 & -2.74 & 0.01 & 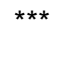 & -3.70 \\
\hline Unemployed : & -3.50 & 1.79 & -1.96 & 0.05 & * & -2.84 \\
\hline Unable to work - & -0.77 & 2.73 & -0.28 & 0.78 & & -0.63 \\
\hline Retired . & -1.41 & 91.57 & -0.90 & 0.37 & & -1.15 \\
\hline Cars in household (hh) & -1.19 & 0.44 & -2.70 & 0.01 & 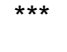 & -0.97 \\
\hline Alternative drive cars in hh & 8.31 & 1.15 & 7.25 & 0.00 & *** & 6.74 \\
\hline \multicolumn{7}{|c|}{ Attitude \& Support of government actions } \\
\hline Education of public & 0.49 & 0.23 & 2.12 & 0.03 & ** & 0.40 \\
\hline Vehicle labelling & 0.30 & 0.22 & 1.34 & 0.18 & & 0.25 \\
\hline Stricter limits car efficiency & 0.35 & 0.19 & 1.84 & 0.07 & * & 0.28 \\
\hline Higher fuel taxes & 1.77 & 0.11 & 15.38 & 0.00 & $* * \star$ & 1.43 \\
\hline Price bonus & 0.04 & 0.21 & 0.21 & 0.83 & & 0.04 \\
\hline Investment in PT & -0.35 & 0.19 & -1.87 & 0.06 & * & -0.29 \\
\hline Active in environmental org. & 6.88 & 1.00 & 6.88 & 0.00 & 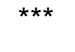 & 5.59 \\
\hline Trust Index & 1.50 & 0.24 & 6.20 & 0.00 & $* * *$ & 1.22 \\
\hline \multicolumn{7}{|l|}{ Country } \\
\hline Australia - & -- & -- & -- & -- & & -- \\
\hline Canada $\cdot$ & 0.09 & 1.50 & 0.06 & 0.95 & & 0.07 \\
\hline Chile - & 7.56 & 1.79 & 4.23 & 0.00 & $* * *$ & 6.14 \\
\hline France : & 0.96 & 1.42 & 0.68 & 0.50 & & 0.78 \\
\hline Israel • & 3.43 & 1.63 & 2.10 & 0.04 & ** & 2.78 \\
\hline Japan - & 2.01 & 1.52 & 1.33 & 0.18 & & 1.63 \\
\hline Korea - & 12.65 & 1.52 & 8.34 & 0.00 & $* * *$ & 10.27 \\
\hline Netherlands . & 26.33 & 2.47 & 10.67 & 0.00 & $* * *$ & 21.37 \\
\hline Spain - & -0.75 & 1.56 & -0.48 & 0.63 & & -0.61 \\
\hline Sweden - & 0.74 & 1.63 & 0.45 & 0.65 & & 0.60 \\
\hline Switzerland . & 0.28 & 1.45 & 0.19 & 0.85 & & 0.22 \\
\hline Number of obs. & 5914 & & Log-Likelihood & & & -21173.51 \\
\hline Left-censored obs. & 1541 & & Chi-square (28) & & & 1138.93 \\
\hline Right-censored obs. & 34 & & sigma & & & 23.49 \\
\hline
\end{tabular}




\section{WTP a price premium for an electric car}

Besides the country constants, there are several variables which have a significant influence on respondents' willingness-to-pay a higher price for an electric vehicle. People who are in favour of government actions reducing $\mathrm{CO}_{2}$ emissions and express more trust in the information they receive on the environmental impacts of products, are more open to paying a higher price for an electric vehicle.

As Figure 11 shows, respondents who support government actions to reduce motor vehicle $\mathrm{CO}_{2}$ emissions are willing to contribute to the environment by paying a higher price for an electric vehicle. Support for higher taxes on automotive fuels has the highest impact, followed by public education on the environmental impacts of private transport. Support for investment in public transport infrastructure has a negative impact, for two possible reasons: on the one hand the government action of investing in public infrastructure is not as closely related to environmental contributing factors as the others; and, on the other hand, respondents who prefer using public transport might not want to buy a vehicle at all.

The index of the trustworthiness of information on claims about the environmental impact of products has a strong and significant positive influence on WTP. Manufacturers and retailers as well as NGOs were considered to be most trustworthy. Politically active people are more likely to be willing to pay a higher price for an electric car.

Respondents already experienced with alternative-fuel vehicles are more likely to be willing to pay more than the average price of a car for an electric car. The number of cars in a household, on the other hand, has a negative effect on the willingness to pay which means that the more cars respondents own, the less likely they are to be willing to pay a price premium. This could be due to the fact that owning several cars is not a sign of environmental awareness. Alternatively, there could be some confusion amongst respondents that the question was seeking to elicit demand for another car.

The annual household income has a small effect on WTP. People with higher incomes are more likely to pay more for an electric car. As the means comparison shows, the effect of being unemployed, retired or unable to work is stronger than other effects, with negative consequence for WTP. Young students, the reference case, are most likely to pay a higher price for an electric vehicle. Household size has a positive effect on WTP: the larger the household, the more likely it is to purchase a sustainable, fuel-efficient car.

As Figure 11 shows, respondents from the Netherlands and Korea both have high WTP more for electric vehicles. Hence the impact of both country constants is strong in the estimated model. 
Figure 11. Impact on WTP premium

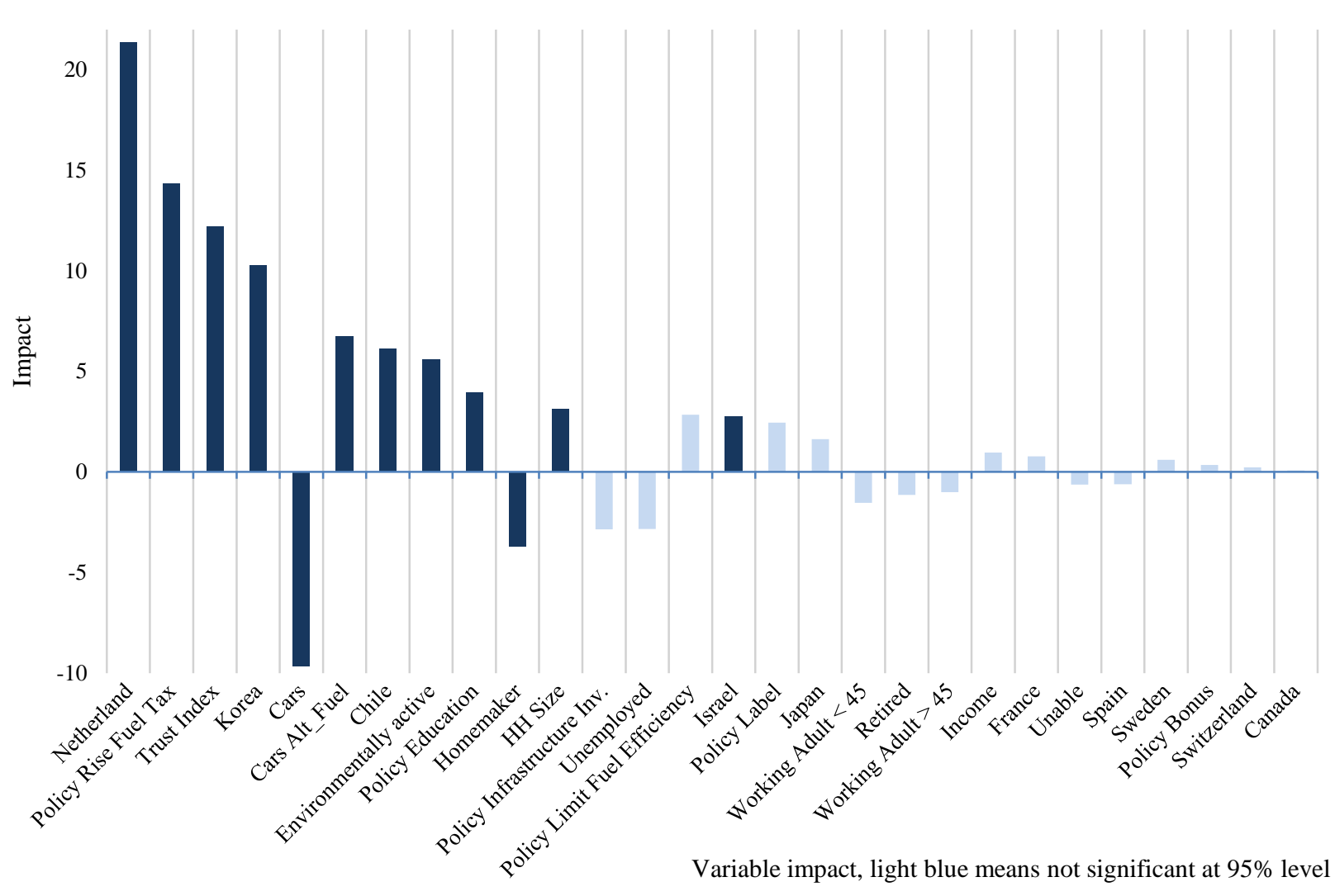




\section{IMPORTANCE OF ENVIRONMENTAL FACTORS RELATIVE TO OTHER ATTRIBUTES IN CAR CHOICE}

This section illustrates the comparison of environmental factors with other attributes in choosing a new car. In the survey, respondents were asked to rank eight vehicle characteristics in order of importance, from 0 (not important at all) to 10 (very important). In Figure 12, three attributes can be identified as most important for car choice: price, reliability and safety. The importance of environmental impacts and brand affinity is not as strong, although the range between the quartiles of the environmental attribute is very large.

Figure 12. Overview importance of attributes in car choice, all countries



Note: The shaded bar in this boxplot indicates the lower ( $25 \%$ of respondents gave at least this importance) and upper ( $75 \%$ of respondents) quartiles, while the line in the box indicates the median (50\% of respondents). There is no line in the box for fuel consumption because the median is 8 as well as the lower quartile. Min outliers are all zero, meaning that for all characteristics there was at least one respondent that attributed zero importance.

\section{$1 \quad$ Methodology}

There are many ways to analyse ranked dependent variables. One method is an ordered logit or probit model. After modelling the data with an ordered logit, the test of parallel slopes (proportional odds assumption) failed (Hedeker 2008). Furthermore, since there are a large number of ranks (ten), it is plausible to treat the categorical variable as continuous (for example Rhemtulla et al. 2012 and Menard 2002). The regression function was written as follows:

$$
\begin{gathered}
y_{i}=\alpha+\beta_{-}(\text {CarChoice } i) \cdot X_{-} \text {CharChoice }+\beta_{-}(\text {SoEc } i) \cdot X_{-} \operatorname{SoEc}+\beta_{-}(\text {At } i) \cdot X_{-} \text {At }+\beta_{-}(\text {Country } i) \\
\cdot X_{-} \text {Countr }+\varepsilon_{i}
\end{gathered}
$$


ENV/WKP(2014)15

Table 7. Mean importance of car choice attributes, by country

\begin{tabular}{|c|c|c|c|c|c|c|c|c|c|c|}
\hline Country & & $\begin{array}{l}\text { Brand } \\
\text { affinity }\end{array}$ & $\begin{array}{l}\text { Environmental } \\
\text { impacts }\end{array}$ & Handling & Comfort & $\begin{array}{c}\text { Fuel } \\
\text { consum- } \\
\text { ption }\end{array}$ & Reliability & Safety & Price & $\mathbf{N}$ \\
\hline \multirow[t]{2}{*}{ Australia } & $\bar{x}$ & 6.16 & 6.61 & 8.05 & 7.94 & 8.12 & 8.67 & 8.43 & 8.50 & \\
\hline & $\mathrm{s}$ & 2.51 & 2.30 & 1.63 & 1.53 & 1.67 & 1.35 & 1.57 & 1.53 & 996 \\
\hline \multirow[t]{2}{*}{ Canada } & $\bar{x}$ & 6.35 & 7.04 & 7.98 & 8.08 & 8.21 & 8.81 & 8.55 & 8.76 & \\
\hline & $\mathrm{s}$ & 2.51 & 2.27 & 1.71 & 1.50 & 1.65 & 1.26 & 1.52 & 1.46 & 1122 \\
\hline \multirow[t]{2}{*}{ Chile } & $\bar{x}$ & 7.60 & 7.96 & 9.04 & 8.82 & 9.05 & 8.94 & 9.24 & 9.07 & \\
\hline & $\mathrm{s}$ & 2.42 & 2.11 & 1.37 & 1.41 & 1.47 & 1.40 & 1.17 & 1.41 & 1027 \\
\hline \multirow[t]{2}{*}{ France } & $\bar{x}$ & 6.67 & 7.01 & 7.29 & 7.83 & 8.19 & 8.34 & 8.25 & 8.55 & \\
\hline & $s$ & 2.33 & 2.05 & 1.83 & 1.50 & 1.60 & 1.46 & 1.55 & 1.48 & 1227 \\
\hline \multirow[t]{2}{*}{ Israel } & $\bar{x}$ & 5.80 & 7.19 & 7.97 & 8.40 & 8.80 & 8.92 & 9.09 & 8.96 & \\
\hline & $s$ & 2.77 & 2.28 & 1.84 & 1.54 & 1.47 & 1.30 & 1.35 & 1.42 & 1168 \\
\hline \multirow[t]{2}{*}{ Japan } & $\bar{x}$ & 6.72 & 6.66 & 7.85 & 7.63 & 7.99 & 8.02 & 8.26 & 8.49 & \\
\hline & $s$ & 2.18 & 1.98 & 1.59 & 1.58 & 1.69 & 1.60 & 1.63 & 1.50 & 1043 \\
\hline \multirow[t]{2}{*}{ Korea } & $\bar{x}$ & 7.29 & 7.48 & 7.95 & 8.14 & 8.75 & 8.37 & 8.87 & 8.74 & \\
\hline & $\mathrm{s}$ & 1.76 & 1.78 & 1.54 & 1.38 & 1.32 & 1.35 & 1.23 & 1.33 & 1116 \\
\hline \multirow[t]{2}{*}{ Netherlands } & $\bar{x}$ & 7.42 & 6.60 & 7.29 & 7.65 & 7.67 & 8.16 & 8.11 & 8.08 & \\
\hline & $\mathrm{s}$ & 1.74 & 1.93 & 1.52 & 1.35 & 1.50 & 1.19 & 1.28 & 1.40 & 1301 \\
\hline \multirow[t]{2}{*}{ Spain } & $\bar{x}$ & 6.78 & 7.39 & 8.21 & 8.19 & 8.50 & 8.50 & 8.75 & 8.61 & \\
\hline & $\mathrm{s}$ & 2.24 & 1.99 & 1.39 & 1.36 & 1.44 & 1.35 & 1.32 & 1.43 & 1101 \\
\hline \multirow[t]{2}{*}{ Sweden } & $\bar{x}$ & 5.38 & 6.75 & 7.85 & 7.98 & 8.03 & 8.60 & 8.45 & 8.36 & \\
\hline & $\mathrm{s}$ & 2.83 & 2.48 & 1.72 & 1.70 & 1.94 & 1.38 & 1.68 & 1.69 & 1012 \\
\hline \multirow[t]{2}{*}{ Switzerland } & $\bar{x}$ & 6.15 & 7.41 & 7.48 & 7.61 & 8.17 & 8.59 & 8.56 & 8.34 & \\
\hline & $\mathrm{s}$ & 2.77 & 2.02 & 1.96 & 1.89 & 1.69 & 1.39 & 1.55 & 1.72 & 1089 \\
\hline \multirow[t]{2}{*}{ Total } & $\bar{x}$ & 6.77 & 7.11 & 7.79 & 8.00 & 8.33 & 8.45 & 8.56 & 8.57 & \\
\hline & $\mathrm{s}$ & 2.30 & 2.08 & 1.68 & 1.49 & 1.59 & 1.37 & 1.45 & 1.47 & 12202 \\
\hline
\end{tabular}

Note: $\bar{x}$ indicates the mean, $\mathrm{s}$ the standard deviation and $\mathrm{N}$ the number of respondents.

The single importance of various factors on car choice variable was estimated depending on the importance of factors when buying a car (CarChoice), as well as socio-economic (SoEc) and attitudinal variables $(A t)$ and the country constants (Country). $\beta$ represents the different impacts of the single variables on the dependent variable $y_{i}$.

Again, the variable reflecting the number of children was deleted from the final models as it correlates highly with household size. Some attitudinal variables which are highly correlated with each other were also deleted. Several variables (e.g. region, number of cars, employment) showed no significant effect in any model, so they were not included.

Table 8 presents the estimated $\beta$ parameters, their significance level and the model fit for every single car choice attribute. The interpretation provided in this section will however focus on the importance of environmental factors when buying a car. 
Table 8. Estimates for the car choice models

\begin{tabular}{|c|c|c|c|c|c|c|c|c|}
\hline & Brand & Environm. & Handling & Comfort & FuelC. & Reliability & Safety & Price \\
\hline Const & $-1.513 * *$ & 0.157 & 1.013 ** & -0.259 & $1.993 * *$ & $1.542 * *$ & 0.040 & $5.124 * *$ \\
\hline \multicolumn{9}{|l|}{ Socio-economic } \\
\hline HH Size (log) & $-0.135 * *$ & $0.150 * *$ & -0.004 & -0.002 & 0.047 & $-0.066 * *$ & 0.044 & -0.033 \\
\hline Income (log) & $0.175 * *$ & $-0.226 * *$ & 0.006 & $0.109 * *$ & $-0.109 * *$ & 0.036 & $0.101 * *$ & $-0.226 * *$ \\
\hline Female & -- & -- & -- & -- & -- & -- & -- & -- \\
\hline Male & 0.087 & $-0.117 * *$ & $-0.117 * *$ & $0.104 * *$ & $0.055 *$ & $0.111 * *$ & $-0.225 * *$ & -0.029 \\
\hline Age $<25$ & -- & -- & -- & -- & -- & -- & -- & -- \\
\hline Age $25-34$ & $-0.198 *$ & $0.347 * *$ & 0.017 & -0.010 & -0.064 & 0.014 & 0.060 & 0.015 \\
\hline Age $35-44$ & $-0.184 *$ & $0.523 * *$ & -0.090 & -0.022 & -0.083 & 0.091 & 0.048 & -0.013 \\
\hline Age $45-54$ & $-0.253 * *$ & $0.603 * *$ & -0.115 & -0.053 & $-0.111 *$ & $0.159 * *$ & 0.079 & -0.099 \\
\hline Age 55+ & $-0.339 * *$ & $0.701 * *$ & $-0.161 * *$ & -0.044 & -0.005 & $0.151 * *$ & $0.194 * *$ & $-0.162 * *$ \\
\hline Altern. drive car in hh & $0.288 * *$ & $0.141 * *$ & 0.080 & $0.088 *$ & 0.042 & $-0.097 * *$ & -0.035 & $-0.142 * *$ \\
\hline \multicolumn{9}{|l|}{ Attitude } \\
\hline High Env. Concern & $-0.162 *$ & $1.046 * *$ & 0.007 & -0.068 & $0.198 * *$ & $0.289 * *$ & 0.048 & 0.060 \\
\hline Medium Env. Concern & -0.047 & $0.659 * *$ & -0.009 & $-0.096 * *$ & 0.079 & 0.031 & 0.026 & 0.039 \\
\hline Low Env. Concern & -- & -- & -- & -- & -- & -- & -- & -- \\
\hline Active in environ. org. & $-0.209 * *$ & $0.318 * *$ & -0.093 & $-0.124 * *$ & $-0.099 * *$ & -0.020 & $0.072 *$ & -0.089 \\
\hline Trust Index & $0.152 * *$ & $0.116 * *$ & 0.014 & -0.002 & -0.012 & $-0.036 * *$ & -0.013 & 0.003 \\
\hline Policy Index & $0.038 *$ & $0.303 * *$ & -0.015 & $-0.021 * *$ & $0.055 * *$ & 0.000 & 0.014 & 0.000 \\
\hline \multicolumn{9}{|l|}{ Car Choice Attributes } \\
\hline Price & -0.028 & $-0.099 * *$ & $0.034 *$ & $0.057 * *$ & $0.333 * *$ & $0.129 * *$ & $0.067 * *$ & -- \\
\hline Safety & $-0.076 * *$ & $0.149 * *$ & $0.141 * *$ & $0.268 * *$ & $0.192 * *$ & $0.308 * *$ & -- & $0.098 * *$ \\
\hline Reliabilitiy & $0.111 * *$ & 0.030 & $0.179 * *$ & $0.197 * *$ & $0.128 * *$ & -- & $0.318 * *$ & $0.196 * *$ \\
\hline Fuel Consumption & $-0.096 * *$ & $0.358 * *$ & $0.044 * *$ & -0.004 & -- & $0.094 * *$ & $0.145 * *$ & $0.372 * *$ \\
\hline Comfort & $0.398 * *$ & $0.070 * *$ & $0.330 * *$ & -- & -0.005 & $0.160 * *$ & $0.225 * *$ & $0.070 * *$ \\
\hline Handling & $0.281 * *$ & $0.090 * *$ & -- & $0.234 * *$ & $0.035 * *$ & 0.103 ** & $0.083 * *$ & $0.030 *$ \\
\hline Environment & $0.059 * *$ & -- & $0.062 * *$ & $0.034 * *$ & $0.193 * *$ & 0.012 & $0.061 * *$ & $-0.059 * *$ \\
\hline Brand & -- & $0.034 * *$ & $0.112 * *$ & $0.113 * *$ & $-0.030 * *$ & $0.025 * *$ & $-0.018 * *$ & -0.010 \\
\hline \multicolumn{9}{|l|}{ Country } \\
\hline Australia & -- & -- & -- & -- & -- & -- & -- & -- \\
\hline Canada & 0.129 & $0.240 * *$ & $-0.236 * *$ & 0.080 & -0.089 & 0.007 & 0.038 & $0.145 * *$ \\
\hline Chile & $1.027 * *$ & $-0.482 * *$ & $0.255^{* *}$ & $0.344 * *$ & 0.026 & $-0.462 * *$ & $0.307 * *$ & $-0.199 * *$ \\
\hline France & $0.748 * *$ & $0.356 * *$ & $-0.722 * *$ & $0.130 * *$ & 0.091 & $-0.213 * *$ & 0.025 & 0.091 \\
\hline Israel & $-0.494 * *$ & $-0.299 * *$ & $-0.406 * *$ & $0.332 * *$ & $0.121 *$ & $-0.140 * *$ & $0.369 * *$ & -0.028 \\
\hline Japan & $0.786 * *$ & 0.083 & 0.022 & $-0.158 * *$ & 0.021 & $-0.556 * *$ & $0.159 * *$ & $0.201 * *$ \\
\hline Korea & $1.175 * *$ & $-0.149 *$ & $-0.410 * *$ & $0.111 *$ & $0.240 * *$ & $-0.618 * *$ & $0.396 * *$ & -0.055 \\
\hline Netherlands & $1.520 * *$ & $0.395 * *$ & $-0.592 * *$ & -0.045 & -0.074 & $-0.170 * *$ & $0.124 * *$ & -0.092 \\
\hline Spain & $0.445 * *$ & -0.010 & -0.043 & $0.139 * *$ & 0.039 & $-0.421 * *$ & $0.259 * *$ & $-0.125 * *$ \\
\hline Sweden & $-0.878 * *$ & $0.268 * *$ & -0.103 & $0.165 * *$ & -0.038 & -0.024 & 0.087 & -0.100 \\
\hline Switzerland & 0.201 & $0.780 * *$ & $-0.532 * *$ & $-0.250 * *$ & -0.003 & -0.027 & $0.168 * *$ & -0.019 \\
\hline$n$ & $8^{\prime} 521$ & $8^{\prime} 521$ & $8^{\prime} 521$ & $8^{\prime} 521$ & $8^{\prime} 521$ & $8^{\prime} 521$ & $8^{\prime} 521$ & $8^{\prime} 521$ \\
\hline R-squared & 0.278 & 0.478 & 0.441 & 0.502 & 0.515 & 0.526 & 0.555 & 0.375 \\
\hline $\operatorname{lnL}$ & $-17^{\prime} 950$ & $-15^{\prime} 630$ & $-14^{\prime} 050$ & $-12^{\prime} 580$ & $-12^{\prime} 990$ & $-11^{\prime} 690$ & $-11 ' 820$ & $-13^{\prime} 460$ \\
\hline
\end{tabular}


The results in Figure 13 show that the ranking of a car's fuel consumption has a strong influence on the importance of environmental factors when buying a car. This seems logical, as fuel consumption and the environmental performance of a car are strongly related. Furthermore, the importance of safety attributes in car choice has a strong impact on the dependent variable. Hence it can be stated that people who value the environmental attributes of a car do not want to pass on safety. Price is the only attribute which has a negative effect on the importance of environmental factors. Often, alternative-fuel vehicles are more expensive than less efficient cars. In the model with only Japanese respondents the negative influence of the price is twice as high as in the general model.

Figure 13. Impact on the importance of environmental factors in car choice

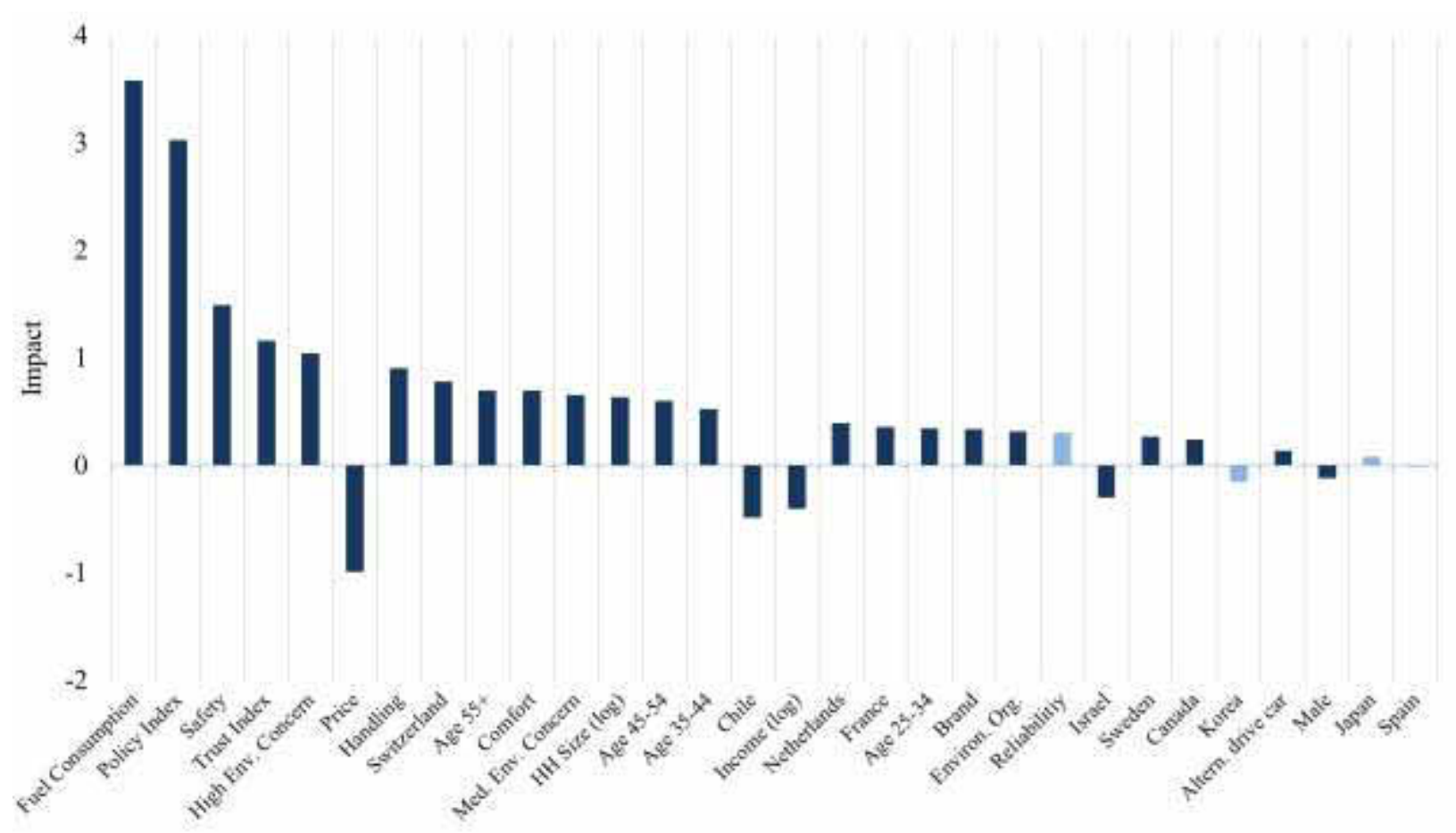

Variable impact, light blue means not significant at $95 \%$ level

Respondents who support government actions to reduce motor vehicle $\mathrm{CO}_{2}$ emissions in general rank the environmental factors as very important car choice attributes. This means that people who are aware of environmental issues and concerns, understandably, tend to buy environmentally friendly cars. In comparing respondents with a low degree of environmental concern to respondents with a medium or high degree of environmental concern, the importance of environmental factors rises. The trustworthiness of the relevant information is also an important factor to respondents who value the environmental characteristics of a car. Being active in an environmental organisation also increases the importance of environmental attributes.

Compared to the "under-25" age group of respondents, the estimated coefficients of the other age groups show that older people give more importance to environmental attributes. The influence of age on the relevance of safety and reliability shows similar findings. Gender has only a slight effect on the value given to environmental attributes. When deciding to buy a car, male respondents tend to think that 
environmental factors are less valuable than reliability or comfort. Only in Korea do male respondents give more importance to environmental attributes than do female respondents. There is a significant but slight negative effect of income on the rank of environmental factors. Therefore, people with higher incomes believe that environmental factors are less important. They seem to be more attuned to brand and comfort. But this could also be explained by the fact that higher-income respondents are more likely to purchase high-end cars, which are less environmentally friendly (more powerful engines are less fuel efficient). Increasing household size is an indicator for families, who are more likely to buy sustainable and safe vehicles. Respondents who already have experience with owning an alternative-fuel vehicle are more likely to value environmental factors when buying a car.

Compared to Australia (the reference case), respondents from other countries differ in their rating of the importance of environmental attributes. The influence for respondents from Switzerland, the Netherlands and France is relatively stronger and more positive. On the other hand the relevance for respondents from Israel, Chile and Korea is lower than in Australia. 
ENV/WKP(2014)15

\section{COMPARISON WITH EXISTING LITERATURE}

The results of the models presented generally support the findings in the literature. While the literature focuses more on the built environment, our results emphasise the importance of travel times somewhat more. However, as discussed above, these findings are complementary if extensive infrastructure is successful in decreasing travel times. The models also confirm the influence of no car ownership found in the literature.

Unlike other studies, the WTP data collected for the 2011 OECD Household Survey on Environmental Behaviour are denoted in percentage points. Ong and Hasselhoff (2005) analysed WTP in terms of percentage points for hybrid cars, but this data was not collected in this survey. This makes it more difficult to compare the results with data from the literature, as the amount derived from percentage units can vary substantially with the increase of the original price of the vehicle. On the other hand, the percentage unit is more suitable for comparing the countries within the study, as price levels differ from one country to another, thereby legitimatising this approach. Compared to other results in the literature, the respondents who are willing to pay more for an electric vehicle are also more environmental friendly. The effect of gender cannot be detected with this dataset. The data did reveal that more highly-educated people are willing to pay a higher price for an electric car. 


\section{OVERVIEW OF POLICY RECOMMENDATIONS}

\section{$1 \quad$ Choice of alternative modes}

The models for all alternative transport choices have consistently shown that socioeconomic variables, except for income, have almost no influence. Even attitudinal variables have a relatively small impact compared to variables that describe the built infrastructure or the situation and environment people live in. The travel time advantage of the car mode is by far the most influential variable and can be attributed to the existing infrastructure, built for car use. This not only includes the density of streets and highways, but also the spatial pattern of shopping facilities, leisure facilities, residential areas and workplaces. The relatively high impact of accessibility to a public transport system supports this interpretation.

The results of the models presented largely support the findings in the literature. Whereas the literature focuses more on the built environment, our results emphasise the importance of travel times. As noted above, these results are complementary if infrastructure is successful in decreasing travel times.

Long travel times are a major obstacle for the use of non-motorised modes and are largely caused by urban planning that places essential services far apart. Long distances between destinations accentuate the need for car ownership. Sensible and intelligent urban planning brings home locations and desired travel destinations closer together. An infrastructure built to better serve non-motorised modes (e.g. allowing pedestrians and cyclists to travel safely and quickly) would reduce car use. Whilst urban planning requires long term policies, simple adjustments to the transportation infrastructure, such as safe bicycle paths, sidewalks, street crossings and shortcuts can be implemented in the short term and at relatively low cost.

Similar things can be said for public transport. Whilst urban design has a clear influence on the usability and necessity of public transport systems, public transport also has the ability to shape urban design. The introduction of new transport lines can be a medium term undertaking, as can measures to improve quality of service and speed (such as prioritisation at crossroads, new vehicles or separate lanes) and can give way to substantial improvements.

It is important to provide the general public with reliable, high quality information about the environmental impacts of the goods they purchase and generally encourage public environmental awareness. A subsidised price on electric cars could enable more people to purchase environmentally friendly vehicles.

\subsection{Walking as a mode choice}

Both the commuting and the shopping model show that the choice of walking is mainly a question of accessibility (distance and geography) and necessity (low income and car ownership). According to the model, more walking could be achieved through less car ownership and shorter distances between key destinations. Policies therefore should aim to improve urban planning and increase the mix of residential and business zones in order to reduce travel distances and times. More short term policies should improve the infrastructure for pedestrians: in many cases pedestrians are forced to walk streets with heavy traffic and make big detours to cross them. More direct routes could decrease walking distances substantially and make them more enjoyable. Zoning and incentives that promote small shops and businesses instead of 
large shopping malls would make shopping by foot possible in many areas and thereby decrease car driving.

\subsection{Cycling as a mode choice}

To encourage households to choose cycling more often, sensible urban planning should shorten the distances between homes and workplaces and homes and shopping options. Infrastructures in favour of cycling make that transport option more enjoyable, safe and fast. Examples of countries that have excellent cycling infrastructure and a high mode share for cycling are the Netherlands and Denmark. Implementing separate cycling paths and enabling more direct routes are some examples of effective policies.

The substantial impact of car ownership suggests that in places where households do not need cars, commuting and shopping are more likely to be done by bicycle. Urban planning that strives to achieve a greener environment for generations to come must address the long term issue of increased population density and bring residences and desired targets closer together. An infrastructure that better serves nonmotorised modes and enables pedestrians and cyclists to get around quickly is the most effective way to encourage cycling and walking. Although urban planning requires long term policies, simple adjustments to the transportation infrastructure - such as safe cycle paths, sidewalks, street crossings and shortcuts can be implemented in the short term and at relatively low cost.

\subsection{Public transport as a mode choice}

In order to encourage households to use public transport, the services have to be made more attractive in terms of speed (to reduce the comparative time advantage of driving) and accessibility (to reduce the time it takes to reach the public transport network). Furthermore, building an urban environment where households can live well without a car promotes public transport use for both commuting and shopping. For shopping, the most influential variable is income. However, it is possible to increase the number of households that choose not to own a car by promoting a built environment in which an enjoyable life without a car is possible. That would increase the use of all alternative mode choices, including public transport.

While urban planning requires long term policies, simple adjustments to the transportation infrastructure can be implemented in the short term and at relatively low cost. The introduction of new public transport lines may be a medium term undertaking. Measures to improve the service quality or speed of a system (such as prioritisation at traffic lights, new vehicles or separate lanes) can be implemented in relatively short time and would bear substantial effects. While urban design has a clear influence on the usefulness and necessity of public transport systems, public transport also has the ability to shape urban design: the widespread availability of efficient public transport in urban areas reduces road traffic, makes it more comfortable for pedestrians and promotes small businesses and shops, thereby enabling people to shop closer to home or workplace.

\subsection{Car Ownership}

Two of the variables with the highest impact on car ownership - income and household size - are not relevant for policy design. The two variables with high impact that can be influenced by policy are car travel time savings and accessibility of public transport system. The model clearly confirms the idea that car ownership can be decreased by offering people a valid alternative to car use in the form of an extensive, fast and high quality public transport system (Brög et al. 2009). The strong positive correlation between lower car ownership and more intense public transport offerings support this idea. 


\section{Willingness-to-pay a price premium for an electric car}

The estimated model's findings on the willingness-to-pay (WTP) more for an electric vehicle show that it is essential to encourage the environmental awareness of the public. Those who support government actions aimed at reducing $\mathrm{CO}_{2}$ emissions from vehicles are willing to contribute to a cleaner environment and pay a higher price for an electric vehicle. Support of other policy action such as education of the public on the environmental impacts of private transport or stricter limits on vehicle fuel efficiency showed a significant effect on the WTP too. This implies that to be willing to pay a price premium for an electric car one needs to be aware of environmental issues and convinced that political actions can protect the environment. People's trust in information has a strong impact on the WTP as well: it is important to provide them with reliable high quality information about environmental impacts of the products they purchase. As price matters - which can be seen in a number of the models estimated - a subsidised price for electric cars could enable more people (even lower income groups) to purchase environmentally friendly vehicles. The findings show as well that experiences with fuel-efficient and alternative-fuel vehicles have a positive effect on the WTP more for an electric car. We can therefore deduce that as acceptance and experience rise, the willingness to pay more for an electric car will also rise.

\section{Importance of environmental factors relative to other attributes in car choice}

When buying a car, people who are more aware of ecological issues are often more likely to put a higher value on a car's environmental attributes. These respondents support government actions to reduce $\mathrm{CO}_{2}$ emissions and trust the information they receive about the environmental impacts of goods they buy. It should therefore be considered important to improve general public awareness of the environmental issues the world is currently facing (Ampt, 2003), through public information campaigns. Also, it seems apparent that a more informed consumer choice may lead to a positive effect on taking environmental factors into consideration when buying a car. One approach may be to link considerations for personal safety and stability with direct negative consequences brought about by environmental change. Thus, the relatively high influence of these factors on car choice could be utilised to increase the importance of environmental factors.

In this context price matters too. In fact, price is the most important factor for respondents buying a car and has a negative influence on the importance of environmental attributes. Often those factors are cost-intensive, e.g. alternative drive systems increase the end price of cars. Hence, a subsidy for environmentally friendly cars may have a greater impact than a penalty for environmentally inefficient cars. However, higher income households tend to buy less environmentally-friendly cars, as other factors are more relevant to them.

Furthermore, targeting younger age groups with communication efforts and public environmental education seems important to counteract the relatively low priority these age groups attribute to environmental concerns, compared to older generations, as they can positively influence future development. 


\section{REFERENCES}

Achtnicht, M. (2012), "German car buyers' willingness to pay to reduce CO2 emissions", Climatic Change, 113, 679-697.

Ampt, E. (2003), "Voluntary household travel behaviour change-Theory and practice", 10th International Association of Travel Behaviour Research Conference, Lucerne, August 2003.

Axsen, J., D.C. Mountain and M. Jaccard (2009), "Combining stated and revealed choice research to simulate the neighbor effect: the case of hybrid-electric vehicles", Resource Energy Econ, 31, 221238.

Bierlaire, M. (2003), "BIOGEME: A free package for the estimation of discrete choice models", Proceedings of the 3rd Swiss Transportation Research Conference, Ascona, Switzerland.

Brög, W., et al. (2009), "Evaluation of voluntary travel behaviour change: experiences from three continents", Transport Policy, 16, 281-292.

Brown, Z. (2014), "Greening Household Behaviour: Cross-domain comparisons in environmental attitudes and behaviours", OECD Environment Working Papers, No. 68, OECD Publishing, Paris, http://dx.doi.org/10.1787/19970900.

Cervero, R. and K.M. Kockelman (1997), "Travel demand and the 3Ds: Density, diversity, and design", Transportation Research D, 2, 199-219.

Dagsvik, J.K., et al. (2002), "Potential demand for alternative fuel vehicles", Transportation Research B 36, 361-384.

Erdem, C., I. Senturk and T. Simsek (2010), "Identifying the factors affecting the willingness to pay for fuel-effcient vehicles in Turkey: A case of hybrids", Energy Policy, 38, 3038-3043.

Ewing, G. and E. Sarigollu (2000), "Assessing consumer preference for clean-fuel vehicles: A discrete choice experiment", Journal of Public Policy and Marketing, 19, 106-118.

Frank, L.D., et al. (2008), "Urban form, travel time, and cost relationships with work and non-work tour complexity and mode choice", Transportation, 35, 37-54.

Frank, L. and G. Pivo (1994), "The impacts of mixed use and density on the utilization of three modes of travel: the single occupant vehicle, transit, and walking”, Transportation Research Record, 1466, 44-52.

Greene, W. H., C. Zhang (2003), "Econometric analysis (5)”, Pearson Education Inc., Upper Saddle River.

Hedeker, D. (2008), "Multilevel models for ordinal and nominal variables", Handbook of multilevel analysis, 237-274.

Hess, P.M., et al. (1999), “Site design and pedestrian travel”, Transportation Research Record, 1674, 9-19. 
Hidrue, M.K., et al. (2011), "Willingness to pay for electric vehicles and their attributes", Resource and Energy Economics, 33, 686-705.

Kriström, B. and C. Kiran (2014), "Greening Household Behaviour and Energy", OECD Environment Working Papers, No. 76, OECD Publishing, Paris. http://www.oecd-ilibrary.org/environment/oecdenvironment-working-papers 19970900

Menard, S. (2001), “Applied logistic regression analyses”, Sage Publications, Inc., Thousand Oaks.

Millock, K. (2014), “Greening Household Behaviour and Food”, OECD Environment Working Papers, No. 78, OECD Publishing, Paris, http://dx.doi.org/10.1787/19970900.

Nauges, C. (2014), "Greening Household Behaviour and Water", OECD Environment Working Papers, No. 73, OECD Publishing, Paris, http://dx.doi.org/10.1787/19970900.

OECD (2014), Greening Household Behaviour: Overview from the 2011 Survey - Revised edition, OECD Studies on Environmental Policy and Household Behaviour, OECD Publishing, Paris, http://dx.doi.org/10.1787/9789264214651-en.

OECD (2011), Greening Household Behaviour: The Role of Public Policy, OECD Studies on Environmental Policy and Household Behaviour, OECD Publishing, Paris. http://dx.doi.org/10.1787/9789264096875-en.

Ong, P. and K. Hasselhoff (2005), "High interest in hybrid cars", SCS fact sheet 1, UCLA Lewis Center for Regional Policy Studies.

Palatnik, R.R. et al. (2014), "Greening Household Behaviour and Waste”, OECD Environment Working Papers, No. 76, OECD Publishing, Paris, http://dx.doi.org/10.1787/19970900.

Parkin, J., M. Wardman and M. Page (2008), "Estimation of the determinants of bicycle mode share for the journey to work using census data", Transportation 35, 93-109.

Pinjari, A.R., et al. (2007), "Modeling residential sorting effects to understand the impact of the built environment on commute mode choice", Transportation, 34, 557-573.

Potoglou, D. and P.S. Kanaroglou (2007), "Household demand and willingness to pay for alternative fuelled vehicles", Transportation Research Part D, 12, 264-74.

Rhemtulla, M., P. Brosseau-Liard and V. Savalei (2012), "When can categorical variables be treated as continuous? A comparison of robust continuous and categorical SEM estimation methods under suboptimal conditions", Psychological Methods, 17, 354-373.

Saelens, B.E., J.F. Sallis and L.D. Frank (2003), "Environmental correlates of walking and cycling: Findings from the transportation, urban design, and planning literatures", Annals of Behavioral Medicine, 25, 80-91.

Serret, Y. and Z. Brown (2014), "Greening household behaviour: Overview of results from econometric analysis and policy implications", OECD Environment Working Papers, OECD Publishing, Paris, http://dx.doi.org/10.1787/19970900. 


\section{ANNEX A: DATA SOURCES AND LIMITATIONS}

Based on a sample of more than 12000 respondents in eleven countries, ${ }^{3}$ this thematic report summarises main results on energy from the 2011 OECD periodic surveys on Environmental Policy and Individual Behaviour Change (EPIC) and draws evidence-based policy recommendations. ${ }^{4}$ It builds on earlier work and supplements the overview of the 2011 survey data presented in OECD (2014). ${ }^{5}$

As in all studies involving primary data collection, there can be a sample bias when implementing a survey. Rigorous efforts were made at stratification and quota sampling. The sampling strategy involved stratification across region, gender, age and socio-economic status. The degree to which the country-level samples are representative of the national population is presented for a number of key variables in OECD (2014) in Annex B. However, in some countries (e.g. Chile and Switzerland) not all of these parameters could be included. Nonetheless, as Annex B in OECD (2014) shows, deviations in excess of 20per cent from representativity across these variables, for which quotas were set, were very limited. Response bias can be a second concern. It should be noted that such a bias is not specific to using internet panel-based surveys and responses can be biased by the interviewer in face-to-face interviews and telephone surveys. Given that the subject matter of the OECD survey is not related to information technologies or Internet, except for a very small number of questions (i.e. investment in "smart" meters), there is little reason to believe that this would result in a systematic bias.

It is also important for the reader to bear in mind the fact that all of the data used in the analyses reported here are based upon survey responses. This survey elicited respondents' stated preferences and perceptions. Therefore statistics reported here which relate to objective, verifiable indicators should be interpreted with caution and in some cases there may be 'measurement error'. On the one hand, this may relate to the dependent variable used in the studies. For example, estimates of waste generation and recycling rates may be inexact for some respondents. Similarly, estimates of the percentage of fresh fruit and vegetables consumed which is organic may also be inexact. On the other hand, some respondents may be mistaken about the precise nature of the policy measures to which they are subject. For example, it is possible that some respondents may not be aware that a given policy exists in their country. Similarly, some respondents may mistakenly believe that a policy exists in their country, when in fact it does not. However, it is important to note that for all questions in which there was significant potential for such "measurement error", respondents were given the option to respond that they "did not know" if such a policy was in place. This may relate to both "carrot" (i.e. grants for investment in energy-efficient devices, scrappage bounties for motor vehicles) and "stick" approaches (i.e. price-based measures). Given the large sample size, such observations should not affect the results in an important way. However, in order to ensure robustness of the results, a large number of models were estimated, including models with different country samples. Attention is drawn to important differences.

In general, readers should view these data as exactly what they are: the self-reported behaviours, attitudes and perceptions of representative samples of households from eleven OECD countries. Bearing the limits of such data in mind, it is important to recognise their advantages: information on households' knowledge and perceptions about environmental issues - increasingly recognised as a crucial factor for better understanding behavioural responses to environmental policies - is rarely analysed at such level of detail. Moreover, for many variables such as discrete choices about whether or not a given purchase has been made, there is likely to be very little deviation from a more formal household consumer survey.

\footnotetext{
3 Australia, Canada, Chile, France, Israel, Japan, Korea, the Netherlands, Spain, Sweden and Switzerland. Approximately 1000 households were surveyed in each country.

${ }^{4}$ The first survey was carried out in 2008 in ten countries with a sample of more than 11000 respondents and the main results were presented in the OECD (2011).

${ }^{5}$ The full 2011 EPIC Survey questionnaire in English is provided in OECD (2014) in Annex A.
} 